\title{
Adiponectin: The Potential Regulator and Therapeutic Target of Obesity and Alzheimer's Disease
}

\author{
Jong Youl Kim ${ }^{1, \dagger}$, Sumit Barua ${ }^{1, \dagger}$, Ye Jun Jeong ${ }^{1}$ and Jong Eun Lee ${ }^{1,2, * \mathbb{C}}$ \\ 1 Department of Anatomy, Yonsei University College of Medicine, Seoul 120-752, Korea; \\ jongyoul74@gmail.com (J.Y.K.); drsbarua@gmail.com (S.B.); jyj4453@naver.com (Y.J.J.) \\ 2 BK21 Plus Project for Medical Sciences, and Brain Research Institute, Yonsei University College of Medicine, \\ Seoul 120-752, Korea \\ * Correspondence: jelee@yuhs.ac; Tel.: +82-2-2228-1646 (ext. 1659); Fax: +82-2-365-0700 \\ + co-first authors.
}

Received: 18 June 2020; Accepted: 28 August 2020; Published: 3 September 2020

\begin{abstract}
Animal and human mechanistic studies have consistently shown an association between obesity and Alzheimer's disease (AD). AD, a degenerative brain disease, is the most common cause of dementia and is characterized by the presence of extracellular amyloid beta $(\mathrm{A} \beta)$ plaques and intracellular neurofibrillary tangles disposition. Some studies have recently demonstrated that $\mathrm{A} \beta$ and tau cannot fully explain the pathophysiological development of $\mathrm{AD}$ and that metabolic disease factors, such as insulin, adiponectin, and antioxidants, are important for the sporadic onset of nongenetic AD. Obesity prevention and treatment can be an efficacious and safe approach to $\mathrm{AD}$ prevention. Adiponectin is a benign adipokine that sensitizes the insulin receptor signaling pathway and suppresses inflammation. It has been shown to be inversely correlated with adipose tissue dysfunction and may enhance the risk of AD because a range of neuroprotection adiponectin mechanisms is related to $\mathrm{AD}$ pathology alleviation. In this study, we summarize the recent progress that addresses the beneficial effects and potential mechanisms of adiponectin in AD. Furthermore, we review recent studies on the diverse medications of adiponectin that could possibly be related to $\mathrm{AD}$ treatment, with a focus on their association with adiponectin. A better understanding of the neuroprotection roles of adiponectin will help clarify the precise underlying mechanism of $\mathrm{AD}$ development and progression.
\end{abstract}

Keywords: Alzheimer's disease; metabolic disease; adiponectin; insulin; antioxidants

\section{Introduction}

The global prevalence of obesity has increased at an alarming rate over the years. In 2016, it was estimated that nearly $39 \%$ of adults aged $\geq 18$ years were overweight worldwide, and $13 \%$ were obese [WHO, 2016]. Obesity is generally defined as a body mass index of $>30 \mathrm{~kg} / \mathrm{m}^{2}$ and is mainly caused by physical inactivity and westernized dietary habits. Obesity is a major concern because it is a risk factor for a plethora of metabolic diseases that increase mortality rates. Since obesity causes insulin resistance, it is one of the major risk factors for type 2 diabetes (T2DM). After years of obesity-associated hyperinsulinemia, the insulin secretory function in the pancreas could falter and eventually lead to hyperglycemia. A previous study has suggested that obesity and diabetes are linked to Alzheimer's disease (AD) [1]. The pooled effect size for AD in relation to obesity and diabetes was calculated at 1.59 and 1.54 in longitudinal epidemiological studies of body mass, metabolic syndrome (dyslipidemia, hypertension, abdominal obesity, and insulin resistance), diabetes, and glucose and insulin levels [2]. A clinical study has also shown that an increased number of metabolic and vascular risk factors in midlife is critical for amyloid deposition and could lead to the risk of developing AD during old age [3]. 
Recently, the World Alzheimer Report estimated that the total number of people with AD and dementia is set to triple to 132-152 million cases worldwide by 2050 (World Alzheimer Report 2015). About $60 \%-70 \%$ of dementia cases are caused by $\mathrm{AD}$, a chronic neurodegenerative disease. These dementia cases are often associated with extracellular amyloid beta $(\mathrm{A} \beta)$ plaques and intraneuronal deposits of neurofibrillary tangles (NFTs) in the brain. Hyperphosphorylation of tau protein leads to the formation of NFTs, whereas the accumulation of $A \beta$ forms hard, insoluble plaques (A $\beta$ peptide) [4]. For over two decades, these two proteins have been the main target for AD therapeutics; currently, available treatments for $\mathrm{AD}$ are symptomatic and do not decelerate or prevent the progression of the disease. However, these therapies demonstrate modest but particularly consistent benefits for cognition, global status, and functional ability. The abovementioned studies have suggested that another approach should be considered for the development of AD treatment based on the relationship between AD, obesity, and T2DM. According to the Mayo Clinic AD Patient Registry, 80\% of AD patients had either diabetes or showed impairment in glucose tolerance [5]. Many studies are being conducted to decipher the underlying mechanisms responsible for the association between obesity, T2DM, and AD. In some studies that used a rodent model, a high-fat diet was shown to cause AD pathology due to the accumulation of $A \beta$ peptides and phosphorylated tau proteins, as well as cognitive impairment $[6,7]$.

Adiponectin secreted from the adipose tissue sensitizes the insulin receptor signaling pathway and prevents inflammation. Adiponectin is a protein that modulates a number of metabolic diseases (Figure 1), including diabetes, dyslipidemia, atherosclerosis, and comorbid metabolic dysfunction that occur in cardiovascular diseases such as hypertension. Many studies have indicated that alteration levels of adiponectin in the plasma and cerebrospinal fluid (CSF) correspond to a distinctive condition of mild cognitive impairment (MCI) and AD [8-13]. The reason for the discrepancies among these studies is unclear, but adiponectin may be considered to be a metabolic biomarker for AD.

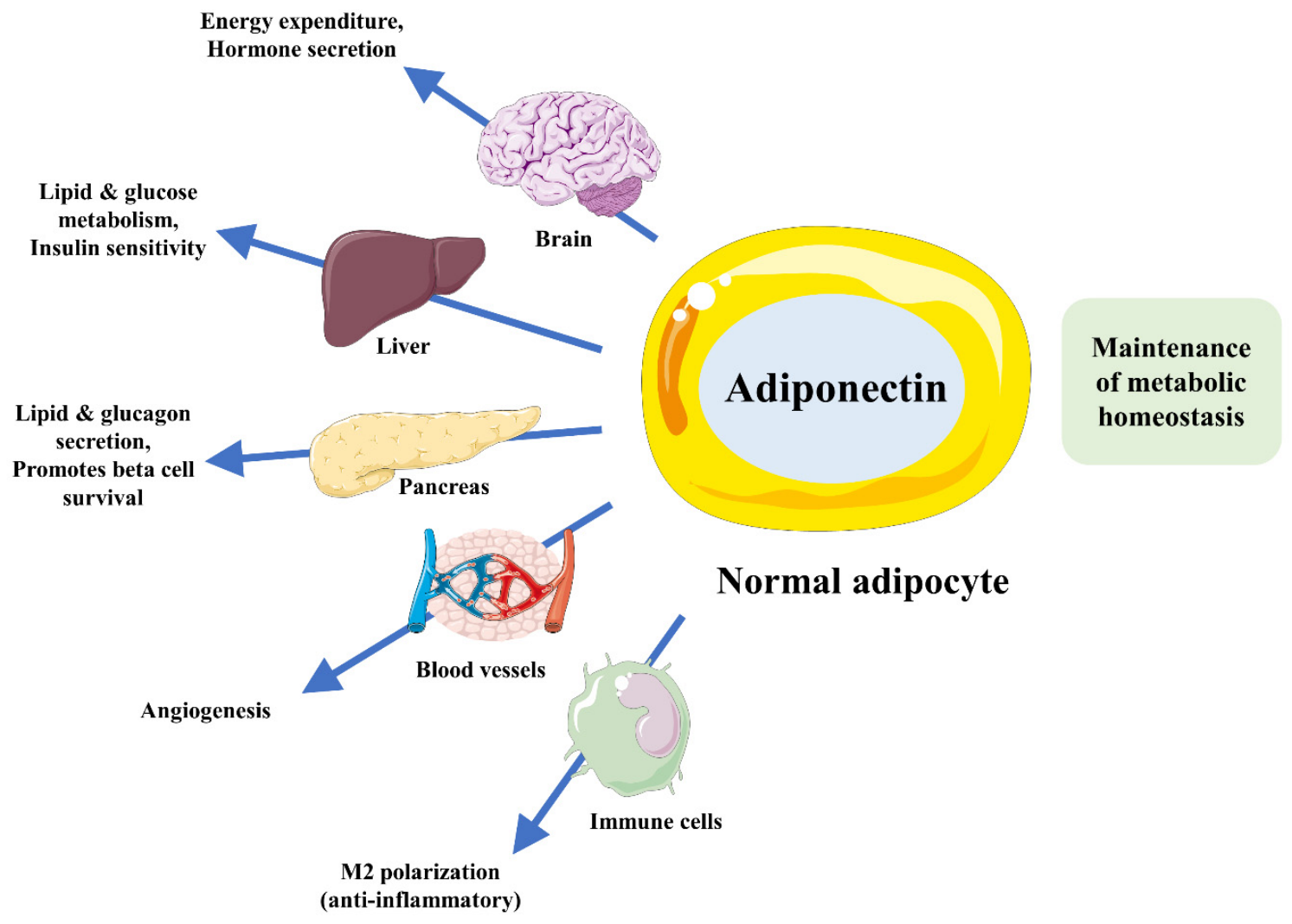

Figure 1. Major mechanisms of adiponectin's actions in the maintenance of metabolic homeostasis. 
In this review, we will discuss the potential mechanisms that bridge the relationship between adiponectin and AD. Understanding these mechanisms could narrow down the process of AD's therapeutic window and also help to design novel therapeutic applications against AD and related neurodegenerative diseases.

\section{Relationship between Metabolic Disorder and Alzheimer's Disease}

The most common age-related neurodegenerative disease is $\mathrm{AD}$, which accounts for the most predominant form (about $60-70 \%$ ) of dementia, as mentioned by WHO. It is characterized by a gradual loss of learning and memory, particularly episodic memory, and may lead to death within 10 years of onset [14,15]. Limited information is known about the etiology and associated nongenetic risk factors of AD. However, some modifiable events, such as dietary habits, lifestyle, and environmental exposure (toxic chemicals), and the nonmodifiable event of aging are common global factors for $\mathrm{AD}$ pathology $[16,17]$. The prevalence of $\mathrm{AD}$ is higher in developed countries than in developing countries, and $>40 \%$ of $\mathrm{AD}$ cases are known to occur in individuals aged $\geq 80$ years.

$\mathrm{AD}$ was named after Alois Alzheimer, the first person to describe that extensive neuronal tangles and amyloid plaques, considered to be important hallmarks of the disease, can be found in the AD brain. However, recent studies have shown that AD patients have an insidious loss of neurons and increased reactive gliosis in different parts of the brain, comprising the cerebral cortex and the limbic system, including the amygdala and hippocampus [18]. Cellular changes in the basal ganglia, cerebellum, brain stem, and spinal cord are relatively spared in AD. According to pathological findings of affected AD brain regions, two different types of aggregates are commonly found in the intracellular and extracellular compartments-the intracellular aggregates are known as NFTs and the extracellular aggregates are known as senile plaques that consist of insoluble paired helical filaments of hyperphosphorylated tau protein $[19,20]$. The major component of the senile plaque is known as $A \beta$ aggregation, which occurs before other pathological events such as NFT formation and neuronal death [21]. Thus, $A \beta$ aggregation is considered the central player of neuronal death, which has also been observed in in-vitro neuronal cells subjected to synthetic $A \beta$ peptide (A $\beta 1-42 / 43)$ treatment [22]. Over the years, the amyloid hypothesis, a process where extracellular $A \beta$ accumulation is followed by the loss of synapses and subsequent neuronal loss, has become the popular concept of AD pathogenesis and has been used by many $\mathrm{AD}$ research groups [23].

It has been suggested that metabolic impairment and modification of the AD-related protein levels can contribute to a higher prevalence of AD. Dyslipidemia, hypertension, abdominal obesity, and insulin resistance are the popular hallmarks of metabolic abnormalities, which are collectively known as metabolic syndrome (MetS) [24]. Individuals with higher life expectancy (above 80 years) have a higher prevalence of MetS, which is a potential cause of neurodegenerative diseases, especially cognitive impairment and dementia. Other studies have also found that MetS is not solely responsible for AD progression in elderly people, regardless of their backgrounds. Higher MetS could bridge inappropriate regulation of the central nervous system (CNS) function (especially part of the limbic system, such as the prefrontal cortex, hippocampus, and amygdala) and metabolic regulatory responses that result in functional cognitive impairments [25]. Metabolic products that are produced in peripheral organs, such as estrogen, insulin, cortisol, and leptin, can cross the blood-brain barrier (BBB) and influence cognitive function. However, neuropeptides such as orexin (mice), allastostatin (drosophila), and neuropeptide $Y$ (grass carp) modulate metabolic processes in different animals [26]. In a recent review, Yi et al. suggested that neuropeptide $Y$ receptors in humans can be a promising target for metabolic disorders [27]. Furthermore, food intake and weight gain can be increased by lesions in oxytocin-containing hypothalamic nuclei [28].

Some studies on metabolic diseases have reported that metabolic diseases, such as T2DM and obesity, are associated with AD. Metabolic alteration of substances such as T2DM-related insulin receptors [29] and obesity-related adiponectin [30,31] could alter the process of aging and age-related dementia, such as in AD. In a recent study, Nasoohi et al. suggested the relationship of "type 3 diabetes" 
to AD pathology, in which the metabolic syndrome consisting of oxidative stress and neuroinflammation leads to brain insulin resistance [32]. This concept suggests that the thioredoxin-interacting protein (TXNIP) is a key regulator of oxidative stress and inflammasome activation, which is associated with impaired insulin function in the brain. Brain insulin resistance is found to be related to the progressive atrophy of the brain regions of early $\mathrm{AD}$ progression, which are cingulate cortices, medial temporal lobe, prefrontal gyri, and other regions [33]. Along with the discussion above, brain insulin resistance due to metabolic disorders such as diabetes mellitus, metabolic syndrome, and nonalcoholic fatty liver disease are considered to be a prominent component of AD pathology; the maintenance of brain insulin supply should also be a target of AD therapy for individuals with metabolic disorder [34]. Thus, metabolism and neurological disorders are closely related to each other.

\section{Adiponectin as a Modulator of Metabolic Disorder}

Adiponectin is secreted with the bioactive molecule leptin from normal adipose tissues (together, they are called adipokines) [35]. It regulates glucose and fatty acid metabolism by increasing insulin sensitivity of peripheral organs [36-38]. However, small amounts of adiponectin, an adipose-tissuespecific protein, can also be synthesized by other cell types. Paradoxically, the adiponectin level decreases with the increase of central adiposity, which causes obesity [39-41]. Obesity causes damage to several organ systems because it regulates MetS, which can be characterized physiologically as excess weight and pathologically as high triglyceride levels and insulin resistance [42]. Moreover, obesity is related to an increase in cognitive decline and AD [43]. Recently, our laboratory has shown that touchscreen-based behavioral testing of high-fat diet mice led to an impairment in cognitive function compared with cognitive function in normal diet mice [44]. MetS, including obesity, cardiovascular disease, type 2 diabetes, and neurodegenerative disorders, is associated with the regulation of adiponectin expression $[8,45,46]$. Like other hormonal proteins, adiponectin also functions through specific receptors known as adiponectin receptors. Adiponectin receptors have been classified into adiponectin receptor (AdipoR) 1, AdipoR2, and T-cadherin. Through the recruitment of adaptor protein APPL1 by AdipoRs activation, adiponectin signaling regulates a series of signaling pathways [47]. AMP-activated protein kinase (AMPK), peroxisome proliferator-activated receptor- $\alpha$ (PPAR $\alpha$ ), IkB kinase (IKK)/NF-KB/PTEN, IRS1/2-Akt, and Ras-ERK1/2 signaling are examples of downstream adiponectin signaling [48-52]. Adiponectin receptors are found to be expressed throughout the whole brain. Thundyil et al. suggested that in the cortical neurons, AdipoR1 expression is more prominent than AdipoR2 expression [53]. On the other hand, T-cadherin acts as the coreceptor of a unidentified receptor, through which the adiponectin can transmit the metabolic signals [54].

\section{Adiponectin's Potential Role in Alzheimer's Disease}

\subsection{Adiponectin and Brain}

Adiponectin gives a beneficial effect on synaptic regulation and memory in AD (Figure 2). It also promotes synaptic plasticity in AD by improving the hippocampal's long-term potentiation [55]. Adiponectin and its homolog, osmotin, enhance neurite outgrowth and synaptic complexity and improve learning and memory defects in mouse AD models [56-59]. Furthermore, chronic adiponectin deficiency in aged mice leads to AD-like cognitive impairments and pathologies [60]. In a recent clinical study, individuals with higher-than-normal adiponectin levels performed better in cognitive tests, indicating the protective effect of adiponectin against cognitive failure. Furthermore, the study showed that adiponectin could be used to identify the risk of cognitive dysfunction [61]. The upregulation of serum adiponectin expression has been found to be associated with MCI and AD [8]. The adiponectin receptors AdipoR1 and AdipoR2 have approximately $95 \%$ homology between human and mice. They are ubiquitously expressed and structurally related in humans and mice, with variable affinity to different isoforms and predominance in some tissues [62]. The expression of AdipoR1 and AdipoR2 is mainly localized to neurons in the hypothalamus, brainstem, and cortex [22], 
as well as the nucleus basalis of Meynert and the hippocampus, the two main targeted structures in $\mathrm{AD}$ [63]. In the hypothalamus and the brainstem, adiponectin is thought to regulate food intake and energy expenditure via AdipoR1-mediated AMPK signaling [23]. However, low levels of adiponectin in CSF may be compensated by the presence of two high-affinity receptors, AdipoR1 and AdipoR2, in the brain $[64,65]$. Suppression of AdipoR1 can result in metabolic diseases such as obesity and diabetes, which also potentiate spatial learning deficit, memory impairment, and AD pathologies [30]. Hence, studies have evaluated adiponectin and its receptors as therapeutic alternatives for AD.

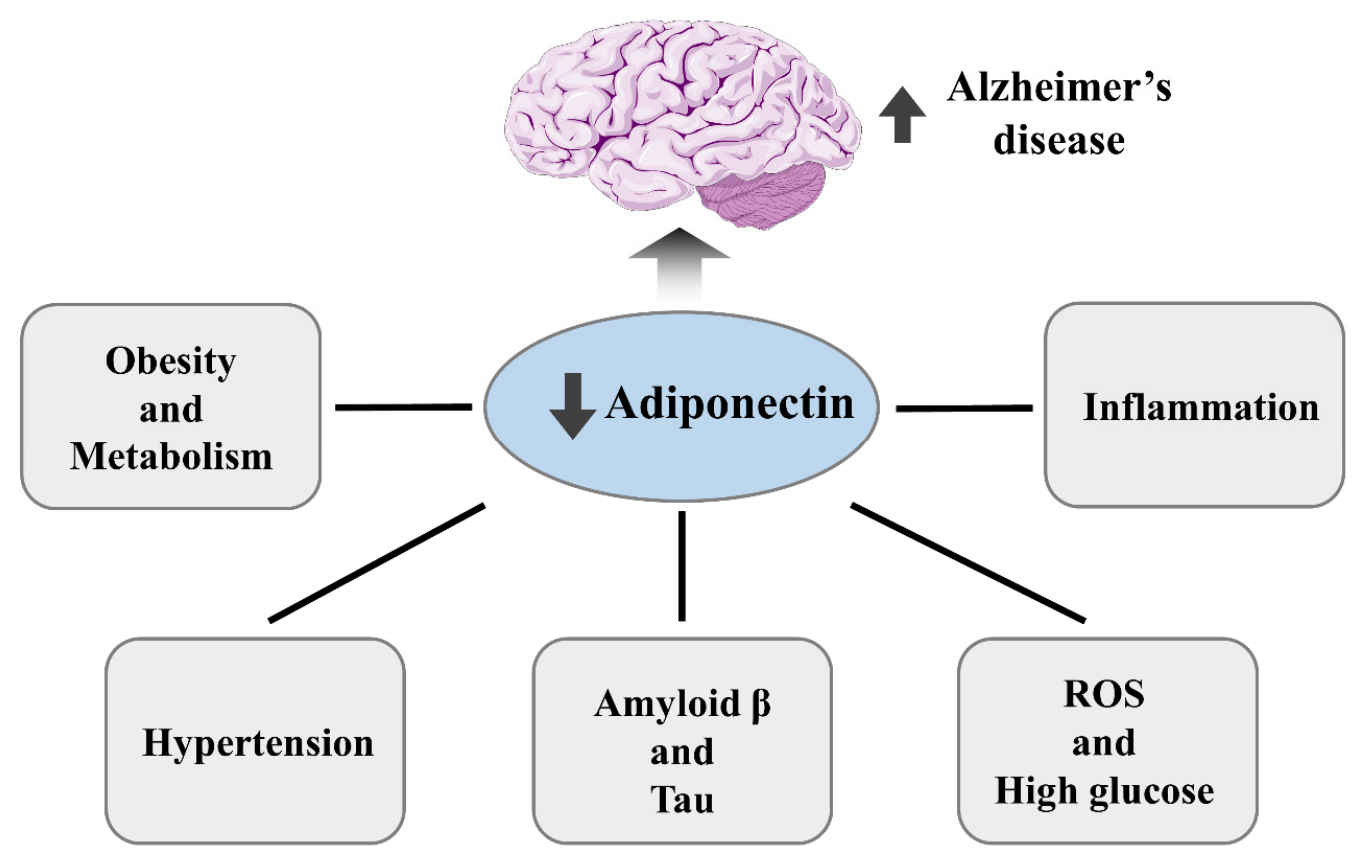

Figure 2. Downregulation of adiponectin involved in the mechanism of Alzheimer's disease exacerbates AD pathology and impairment.

In $\mathrm{AD}, \mathrm{A} \beta$ has to cross $\mathrm{BBB}$ to be transported in the brain, where it is regulated by specific receptors and transporters [66]. Therefore, it is necessary to protect BBB disruption. Adiponectin protects BBB disruption by inhibiting apoptosis of endothelial cells, protecting tight junction integrity via the AdipoR1-mediated NF- $\kappa B$ pathway, and maintaining the balance of $A \beta$ transporters in endothelial cells [67].

\subsection{Adiponectin Improves Insulin Signaling}

Recently, many studies have provided evidence that insulin signaling dysfunction plays a key role in cognitive decline, such as in MCI and AD [68-70]. It is well known that T2DM is independently associated with cognitive dysfunction and loss of hippocampus volume [71]. Further, insulin signaling prevents $A \beta$ oligomer toxicity [72]. Adiponectin has been found to be beneficial for T2DM because of its ability to enhance insulin sensitivity, and it has been used in T2DM treatment [73]. A few studies have reported the relationship between increased diabetes prevalence and decreased levels of adiponectin [74]. In T2DM patients with low adiponectin, the hippocampus volume is significantly decreased [75]. Lower levels of adiponectin in T2DM have also been associated with lower gray matter volume and reduced cerebral glucose metabolism in the temporal brain regions [76]. In addition, adiponectin-deficient mice have been used as models of insulin resistance and the associated memory pathology [60]. In a rat cognitive-deficient model induced by streptozocin, which is commonly used to induce diabetes, adiponectin attenuated tau hyperphosphorylation and alleviated cognitive function by activating the PI3K/Akt/GSK-3 $\beta$ signaling pathway [77]. 


\subsection{Adiponectin Regulates Glucose/Fatty Acid Metabolism}

Deterioration of cerebral glucose metabolism is an important feature in age-related AD and is key to the progression of AD pathogenesis [78-81]. Adiponectin modulates glucose metabolism in hippocampal neurons by increasing glucose uptake, glycolysis, and adenosine triphosphate production rates [82]. Glucose and lactate are considered major energy sources in the brain. However, the amounts of glucose consumption and oxygen utilization in the brain are not the same [83]. In addition, lactate cannot generate energy because of the fast removal of lactate from cells and activated tissues [84]. A study conducted by Dhopeshwarka et al. suggested that there are gaps between glucose consumption and oxygen utilization by the brain and that fatty acids can enter the brain and mitochondria and can be oxidized to produce energy [85]. About 20\% (maximum) of the total energy in the brain can be produced from mitochondrial oxidation of fatty acids [86]. Moreover, fatty acids are regarded as key players in the homeostasis of glucose [87]. Fatty acid metabolism has been found to be related to $\mathrm{MCI}$ and to adiponectin and its receptors in mice fed a high-fat diet $[44,88,89]$. Therefore, changes in adiponectin levels can alter the brain metabolism and progression of AD. Adiponectin also activates the AMPK and PPAR $\alpha$ pathways through AdipoR1 and AdipoR2, respectively, which reduce hepatic lipogenesis and enhance $\beta$-oxidation [90].

\subsection{Adiponectin Alleviates Inflammation}

One of the key factors for cognitive decline (MCI) and AD is chronic neuroinflammation [91-93]. Amongst renowned anti-inflammatory molecules, adiponectin is considered to be an active contributor to chronic inflammation in obesity and T2DM $[91,92,94,95]$. Chronic inflammation, which induces $\mathrm{AD}$ and metabolic-distress-related pathologies such as neuronal insulin resistance, endoplasmic reticulum stress, synaptotoxicity, and neurodegeneration, is caused by the secretion of proinflammatory cytokines by microglial cell activation [92,96]. In an adiponectin-knockout mouse model, activation of proinflammatory cytokines such as interleukin (IL)-1 $\beta$, IL-6, and tumor necrotic factor- $\alpha$ has been shown to cause the development of AD-like pathology [60]. Furthermore, adiponectin prevents neuroinflammation by decreasing microglia and regulating the brain macrophage proinflammatory phenotype $[97,98]$. Therefore, changes in adiponectin levels may be closely related to neuroinflammation in AD.

\subsection{Adiponectin Has Protective Effect on Oxidative Stress/Hypoxia}

Studies have shown that oxidative stress and hypoxia conditions render an important role in the pathogenesis of age-related neurodegenerative diseases such as $\operatorname{AD}[78,99,100]$. Adiponectin alleviates oxidative stress and oxidative-stress-mediated cytotoxicity [101,102] and has a protective effect in high glucose concentrations in blood [26]. Many of these effects have been reported to occur because of upregulated AMPK signaling [101,103]. Since AMPK is considered the general energy sensor in the brain, inhibition of adiponectin may influence the AMPK pathway, which in turn could affect brain metabolism [104,105]. Similarly, in a hypoxic environment in obese individuals, hypertrophic adipocytes upregulate the expression of hypoxia-inducible factor- $1 \alpha$ (HIF-1 $\alpha$ ) [106]. Upregulation of HIF- $1 \alpha$ has been found to inhibit the production of adiponectin. This phenomenon has been confirmed by the expression of high levels of adiponectin mRNA in adipocyte-specific HIF- $1 \alpha$-deficient mice fed a high-fat diet for 7 weeks compared with control mice [107]. With the above study, adiponectin can be considered a modulator of neurocognitive disorders, which might suggest adiponectin as a potential therapeutic target for AD.

\subsection{Adiponectin and Neuroprotection/Neurogenesis}

Adiponectin has a neuroprotective effect in various conditions. It shows a protective effect in brain injury caused by ischemic stroke and intracerebral hemorrhage [108,109]. Neuroprotective effects of adiponectin have also been demonstrated in a kainite-induced excitotoxicity model [103]. 
Furthermore, adiponectin plays a role in many deleterious conditions such as $\mathrm{A} \beta$ deposition/tau phosphorylation, neuroinflammation, and oxidative stress by protecting neurons and glial cells. Hippocampal neurogenesis is crucial for maintaining cognitive function; however, it is impaired in AD patients $[110,111]$. In this respect, it seems necessary to pay attention to the neuroproliferative effect of adiponectin in the adult brain. Intracerebroventricular injection of adiponectin has shown neurogenic and proliferative effects in an adiponectin-deficient mice model [55]. An in-vitro and in-vivo study has also indicated that adiponectin stimulates neurogenesis through AdipoR1 [112].

\section{Adiponectin-Associated Therapeutic Strategy against AD Induced by Metabolic Diseases}

A number of in-vitro, animal, and clinical studies have been conducted to find molecular targets that prevent protein aggregation, oxidative stress, and inflammation for AD treatment. However, a therapeutic target is still unclear. Adiponectin can be considered a protein of interest in the search for new neuroprotective targets for AD. Previous studies have attempted to use adiponectin levels as an AD marker [8-10,13,113] (Table). In addition, numerous therapeutic agents that are being considered new paradigms in AD therapy have been found to be related to adiponectin signaling. These therapeutic agents do not only include adiponectin and AdipoR homologs but also conventional AD drugs, anti-insulin resistance drugs, and cardiovascular drugs.

\subsection{Adiponectin as an AD Marker}

In some recent studies, the relationship between plasma and CSF adiponectin levels in MCI or $\mathrm{AD}$ has been reported. However, there are discrepancies in their results. Some studies have shown decreased adiponectin levels in AD or MCI [113-115], while others have shown increased levels or insignificant changes $[9,11-13,116,117]$. The reason for the discrepancies among these studies might be because of the ambiguous criteria for classifying $\mathrm{AD}$ and MCI patients or failure to exclude other factors that may have affected adiponectin levels. As mentioned earlier, conventional AD medications (acetylcholinesterase inhibitors) can increase serum adiponectin levels. Furthermore, there is also a possibility that increased adiponectin levels may have served as a compensatory mechanism for the progress of $\mathrm{AD}$. Thus, to establish the relationship between adiponectin levels and $\mathrm{AD}$, more controlled studies should be conducted.

\subsection{Adiponectin and Adiponectin Receptor Homolog}

Osmotin, a protein found in tobacco that structurally and functionally mimics adiponectin, positively modulates the AdipoR1/AMPK/SIRT1 pathway and reduces the AD-related protein A $\beta$ expression (Figure 3) [59]. SIRT1 and AMPK are known for their metabolic activities and cellular energy homeostasis; they positively regulate each $[118,119]$. Osmotin treatment has been found to inhibit the expression of $\mathrm{AD}$ markers, such as amyloid precursor protein, $\mathrm{p}$-tau, and $\mathrm{A} \beta$, in inflammation-induced mouse brains $[82,120]$. In addition, adiponectin also enhances neurite outgrowth and synaptic complexity via AdipoR1/NgR1 signaling [57].

Adiporon, an agonist of adiponectin receptors that bind AdipoRs, has been known to play a vital role in many neurological diseases. Its ability as an anti-depressive agent and metabolic regulator has been demonstrated in a mouse model of depression, where it also regulated dopaminergic neurons [121]. It has also been shown to modulate fear and intrinsic excitability in the hippocampus [122]. These beneficial neurological effects are possible because of the BBB-penetrating property of this molecule. More recently, Liu et al. have reported that adiporon improves cognitive dysfunction, inhibits $\mathrm{A} \beta$ deposition, and restores impaired hippocampal neuron proliferation activation in AD mice by activating the AdipoR1/AMPK pathway [123]. Ultimately, osmotin and adiporon can be effective and realistic therapeutic alternatives for adiponectin-based $\mathrm{AD}$ treatment in patients. 


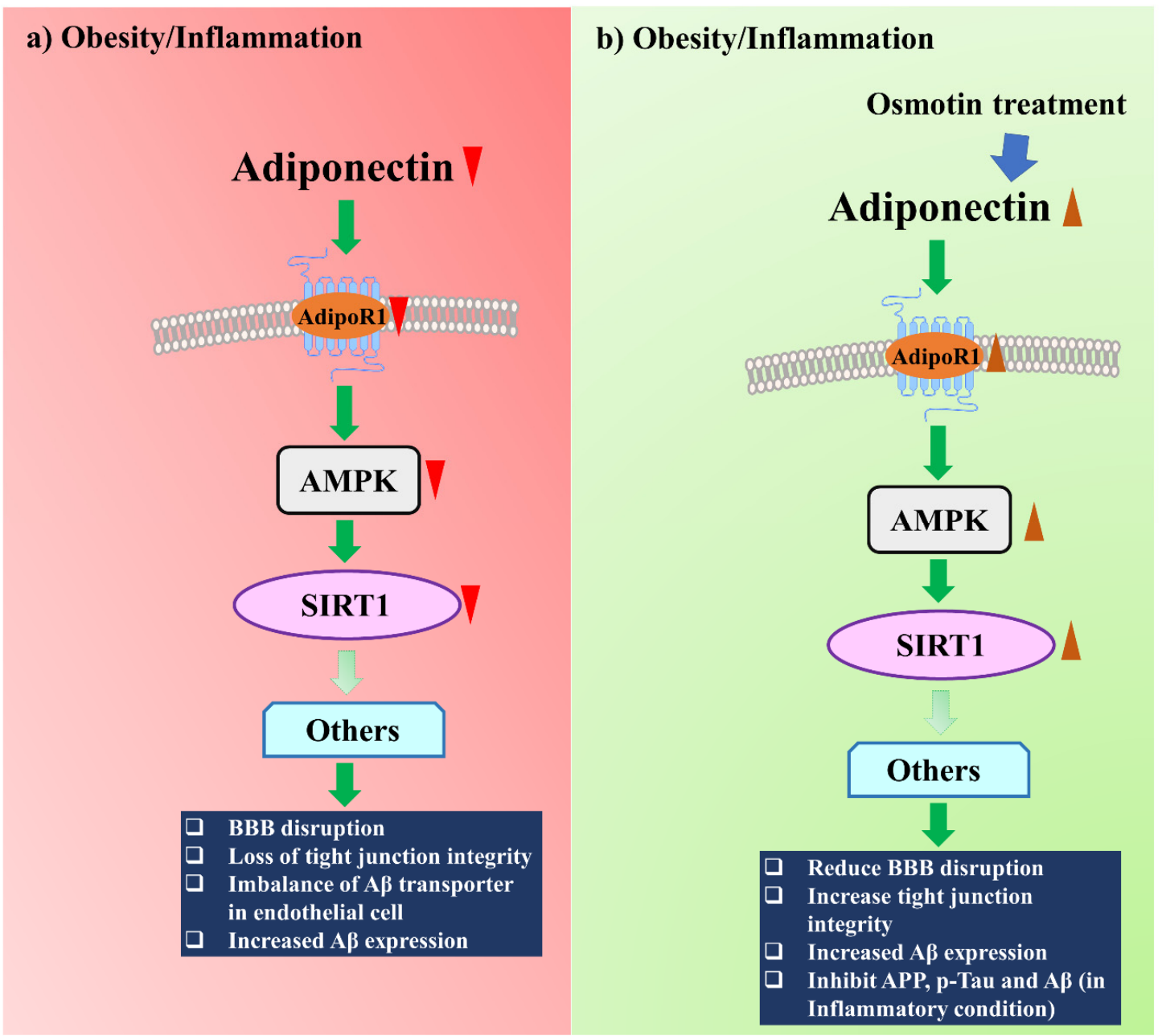

Figure 3. Osmotin treatment positively modulates AD through the AdipoR1/AMPK/SIRT1 pathway. (a) Obesity reduces adiponectin and AdipoR1 expressions, which negatively modulate the AMPK/SIRT1 pathway and increase the AD biomarkers. (b) Osmotin treatment increases adiponectin and AdipoR1 expressions and reduces AD biomarkers through the AMPK/SIRT1 pathway.

\subsection{Adiponectin and Conventional AD Drug}

The US Food and Drug Administration (FDA) has approved only two types of medications for the treatment of cognitive dysfunction of AD-acetylcholinesterase inhibitors (AChEI; donepezil and galantamine) and memantine [124]. One study has shown that donepezil increases serum adiponectin levels in AD patients, while another study has shown that galantamine increases serum adiponectin levels in a type 2 diabetes rat model [125]. A recent study has also reported a significant weight loss after AChEI treatment and that AChEI treatment exerts an insulin-sensitizing effect via the activation of IR/PI3K/Akt/GLUT2,4 and Wnt/GSK3 $\beta / \beta$-catenin signaling [126]. Although more studies are needed, the beneficial effect of AChEI on AD is thought to be possibly mediated by adiponectin.

Memantine is another FDA-approved medication for AD. Although it cannot be factually claimed that its therapeutic mechanism is directly associated with adiponectin, there are some interesting points that suggest a connection between them. Memantine is an N-methyl-D-aspartate (NMDA) receptor antagonist that modulates glutamatergic dysfunction and inhibits excitotoxicity mediated by NMDA [127]. Its therapeutic ability in AD is attributed to this mechanism. Similarly, adiponectin has been shown to have a neuroprotective effect by inhibiting NMDA-mediated excitotoxicity [128]. In addition, adiponectin and memantine play a protective role in glutamate-induced excitotoxicity (shown in both animal/in-vitro models) $[129,130]$. Furthermore, memantine also has the ability to 
attenuate insulin resistance and improve brain function in high-fat diet-induced models. Given these similarities, there is a possibility that the comprehensive role of adiponectin in AD could be a hint in conducting research on memantine.

\subsection{Adiponectin and Type 2 Diabetes Medications}

Several studies have suggested that AD and T2DM are related to each other; thus, T2DM drugs and their potential to be used as AD treatment are drawing attention [131,132]. There are several types of type 2 diabetes drugs, such as biguanide derivatives (metformin), PPAR $\gamma$ agonists (thiazolidinedione [TZD] derivatives), glucagon-like peptide-1 receptor (GLP-1R) agonists, dipeptidyl peptidases 4 (DPP-4) inhibitors, sodium-glucose transport protein 2 inhibitors, and second-generation sulfonylureas [133]. In addition to these drugs' ability to improve cognitive function, some of these drugs are capable of increasing adiponectin levels.

Metformin, the drug used as first-line pharmacologic therapy in T2DM, has been shown to attenuate AD-like pathology in both in-vitro and in-vivo studies [134-136]. An improvement in cognitive function has been observed in many studies on mild cognitive function and dementia patients $[60,137,138]$. Many studies have shown that metformin increases serum adiponectin levels in various conditions [139-141]. Furthermore, like adiponectin, metformin plays a neuroprotective role by activating AMPK signaling [142,143].

TZD derivatives, including rosiglitazone and pioglitazone, act as PPAR $\gamma$ agonists and are used for T2DM treatment because of their insulin sensitization activity $[144,145]$. They have also been researched as alternative AD treatments [146,147]. Increased adiponectin by TZD might play a key role in the insulin sensitization activity induced by TZD $[132,148]$. Thus, TZD's beneficial effect on AD might be related to the increased adiponectin levels.

An insulin-releasing hormone in hyperglycemic conditions, GLP-1, has been found to have a neuroprotective effect [149-151]. GLP-1 receptors are responsible for controlling food intake and body weight and are widely distributed in the brain and special neurons (pyramidal neurons of the hippocampus and neocortex), which means that it plays an important role in neural function and synaptic transmission [149,151-154]. In an AD mice model, Val(8)GLP-1, liraglutide, and exidin-4 (GLP-1 analogs, well known for the upregulation of adiponectin) treatments rescued synaptic plasticity by preventing synaptic degradation, which is also correlated with the increased learning ability of new spatial tasks [155-158]. Several studies have also shown the beneficiary effect of GLP-1 analogs for AD [159-161].

Inhibitors of DPP-4 also increase GLP-1 signaling activation by inhibiting the degradation of GLP-1 [162]. Therefore, they potentially act on AD, like other GLP-1 analogs [163]. They also lead to increased adiponectin and are thought to be alternative medications for AD [164-167]. Accordingly, the GLP-1 functional facilitator, GLP-1 analogs, and DPP-4 inhibitors might be good candidates for AD treatment because of their ability to increase adiponectin.

\subsection{Drugs for Cardiovascular Disease and Adiponectin}

A recent study has suggested that medications aimed at cardiovascular diseases may also decrease the risk of dementia caused by AD [168]. Several neuroprotective pleiotropic agents have been shown to increase plasma adiponectin levels [169]. In studies with animal models, angiotensin II receptor blockers have shown beneficial effects on cognitive function related to AD [170-172]. Improvements in AD progress and cognitive function have also been observed in human clinical trials [173-175]. Moreover, angiotensin II receptor blockers can reduce neuroinflammation directly or by regulating the infiltration of inflammatory cytokines because of their ability to restore the blood-brain barrier [176-178]. Altogether, angiotensin II receptor blockers may be beneficial in AD therapy because it upregulates adiponectin [179-181].

Angiotensin-converting enzyme inhibitors (ACEIs) regulate the renin-angiotensin system and angiotensin II receptor blockers. Upregulation of blood adiponectin has been observed after treatment 
with ACEIs [182,183]. Some clinical and meta-analysis studies have also shown that ACEIs reduce the progression and risk of AD [184-187]. This result has also been observed in several animal model studies [188-190]. However, in one meta-analysis study, ACEIs had no effect on cognitive decline [191], and some studies have shown a negative effect of ACEIs in in-vivo AD models [192-194]. Thus, ACEI treatment is controversial for its effect on AD.

Another cardiovascular medication, fibrate, a PPAR $\alpha$ agonist, has been shown to increase adiponectin levels $[195,196]$. Since ligand-activated PPAR $\alpha$ decreases tau phosphorylation, A $\beta$ pathology, and neuroinflammation, fibrate might be a good candidate for AD treatment [197].

Statins (such as simvastatin, paravastatin, and atorvastatin) have been reported to increase blood adiponectin levels [198-200]. Statins are well known for their anti-inflammatory properties in diabetic patients [201,202]. According to the above studies, statins might also be useful in the treatment of AD by increasing blood adiponectin levels and reducing neuroinflammation.

\section{Conclusions}

The conventional approach to developing therapeutics for AD has been focused on the $\mathrm{A} \beta$ hypothesis, which insists that $\mathrm{A} \beta$ causes $\mathrm{AD}$ pathologies. However, this approach has yet to provide a successful treatment or prevention method for AD. Based on the metabolic alterations that occur in the pathological markers of $\mathrm{AD}$, this review suggests that the adipocyte metabolite adiponectin can be considered a therapeutic option for the treatment of $\mathrm{AD}$.

Author Contributions: J.E.L. provided concept, design, and overall supervision of this study. J.Y.K. and S.B. contributed to the writing and drawing. Y.J.J. participated in the discussion and revision. All authors have read and agreed to the published version of the manuscript.

Funding: This study was supported by a grant from the National Research Foundation of Korea (NRF) through a grant funded by the Ministry of Science, ICT, and Future Planning (NRF-2017R1A2B2005350).

Conflicts of Interest: The authors declare no conflict of interest.

\section{References}

1. Pugazhenthi, S.; Qin, L.; Reddy, P.H. Common neurodegenerative pathways in obesity, diabetes, and Alzheimer's disease. Biochim. Biophys. Acta Mol. Basis Dis. 2017, 1863, 1037-1045. [CrossRef] [PubMed]

2. Profenno, L.A.; Porsteinsson, A.P.; Faraone, S.V. Meta-analysis of Alzheimer's disease risk with obesity, diabetes, and related disorders. Biol. Psychiatry. 2010, 67, 505-512. [CrossRef] [PubMed]

3. Gottesman, R.F.; Schneider, A.L.; Zhou, Y.; Coresh, J.; Green, E.; Gupta, N.; Knopman, D.S.; Mintz, A.; Rahmim, A.; Sharrett, A.R.; et al. Association between midlife vascular risk factors and estimated brain amyloid deposition. JAMA 2017, 317, 1443-1450. [CrossRef] [PubMed]

4. Mucke, L. Neuroscience: Alzheimer's disease. Nature 2009, 461, 895-897. [CrossRef] [PubMed]

5. Janson, J.; Laedtke, T.; Parisi, J.E.; O'Brien, P.; Petersen, R.C.; Butler, P.C. Increased risk of type 2 diabetes in Alzheimer disease. Diabetes 2004, 53, 474-481. [CrossRef]

6. Niu, L.; Han, D.W.; Xu, R.L.; Han, B.; Zhou, X.; Wu, H.W.; Li, S.H.; Qu, C.X.; Liu, M. A high-sugar high-fat diet induced metabolic syndrome shows some symptoms of Alzheimer's disease in rats. J. Nutr. Health Aging. 2016, 20, 509-513. [CrossRef]

7. Ledreux, A.; Wang, X.; Schultzberg, M.; Granholm, A.C.; Freeman, L.R. Detrimental effects of a high fat/high cholesterol diet on memory and hippocampal markers in aged rats. Behav. Brain Res. 2016, 312, 294-304. [CrossRef]

8. Une, K.; Takei, Y.A.; Tomita, N.; Asamura, T.; Ohrui, T.; Furukawa, K.; Arai, H. Adiponectin in plasma and cerebrospinal fluid in MCI and Alzheimer's disease. Eur. J. Neurol. 2011, 18, 1006-1009. [CrossRef]

9. Van Himbergen, T.M.; Beiser, A.S.; Ai, M.; Seshadri, S.; Otokozawa, S.; Au, R.; Thongtang, N.; Wolf, P.A.; Schaefer, E.J. Biomarkers for insulin resistance and inflammation and the risk for all-cause dementia and alzheimer disease: Results from the framingham heart study. Arch. Neurol. 2012, 69, 594-600. [CrossRef] 
10. Waragai, M.; Adame, A.; Trinh, I.; Sekiyama, K.; Takamatsu, Y.; Une, K.; Masliah, E.; Hashimoto, M. Possible involvement of adiponectin, the anti-diabetes molecule, in the pathogenesis of Alzheimer's disease. J. Alzheimers Dis. 2016, 52, 1453-1459. [CrossRef]

11. Khemka, V.K.; Bagchi, D.; Bandyopadhyay, K.; Bir, A.; Chattopadhyay, M.; Biswas, A.; Basu, D.; Chakrabarti, S. Altered serum levels of adipokines and insulin in probable Alzheimer's disease. J. Alzheimer Dis. JAD 2014, 41,525-533. [CrossRef] [PubMed]

12. Ma, J.; Zhang, W.; Wang, H.F.; Wang, Z.X.; Jiang, T.; Tan, M.S.; Yu, J.T.; Tan, L. peripheral blood adipokines and insulin levels in patients with Alzheimer's disease: A replication study and meta-analysis. Curr. Alzheimer Res. 2016, 13, 223-233. [CrossRef] [PubMed]

13. Wennberg, A.M.; Gustafson, D.; Hagen, C.E.; Roberts, R.O.; Knopman, D.; Jack, C.; Petersen, R.C.; Mielke, M.M. Serum adiponectin levels, neuroimaging, and cognition in the mayo clinic study of aging. J. Alzheimers Dis. 2016, 53, 573-581. [CrossRef] [PubMed]

14. Albert, M.S.; DeKosky, S.T.; Dickson, D.; Dubois, B.; Feldman, H.H.; Fox, N.C.; Gamst, A.; Holtzman, D.M.; Jagust, W.J.; Petersen, R.C.; et al. The diagnosis of mild cognitive impairment due to Alzheimer's disease: Recommendations from the national institute on aging-Alzheimer's association workgroups on diagnostic guidelines for Alzheimer's disease. Alzheimers Dement. 2011, 7, 270-279. [CrossRef]

15. Sacks, D.; Baxter, B.; Campbell, B.C.V.; Carpenter, J.S.; Cognard, C.; Dippel, D.; Hirchs, J. Multisociety consensus quality improvement revised consensus statement for endovascular therapy of acute ischemic stroke. Int. J. Stroke 2018, 13, 612-632. [CrossRef] [PubMed]

16. Alzheimer's, Assotiation. Alzheimer's disease facts and figures. Alzheimers Dement. 2016, 12, 459-509. [CrossRef]

17. Van Cauwenberghe, C.; van Broeckhoven, C.; Sleegers, K. The genetic landscape of Alzheimer disease: Clinical implications and perspectives. Genet. Med. 2016, 18, 421-430. [CrossRef]

18. Lee, E.B. Obesity, leptin, and Alzheimer's disease. Ann. N. Y. Acad. Sci. 2011, 1243, 15-29. [CrossRef]

19. Lee, V.M.; Goedert, M.; Trojanowski, J.Q. Neurodegenerative tauopathies. Annu. Rev. Neurosci. 2001, 24, 1121-1159. [CrossRef]

20. Mattson, M.P. Pathways towards and away from Alzheimer's disease. Nature 2004, 430, 631-639. [CrossRef]

21. Morishima, M.; Ihara, Y. Posttranslational modifications of tau in paired helical filaments. Dementia 1994, 5, 282-288. [CrossRef] [PubMed]

22. Han, X.J.; Hu, Y.Y.; Yang, Z.J.; Jiang, L.P.; Shi, S.L.; Li, Y.R.; Guo, M.Y.; Wu, H.L.; Wan, Y.Y. Amyloid beta-42 induces neuronal apoptosis by targeting mitochondria. Mol. Med. Rep. 2017, 16, 4521-4528. [CrossRef] [PubMed]

23. Selkoe, D.J.; Hardy, J. The amyloid hypothesis of Alzheimer's disease at 25 years. EMBO Mol. Med. 2016, 8 , 595-608. [CrossRef] [PubMed]

24. Bussler, S.; Penke, M.; Flemming, G.; Elhassan, Y.S.; Kratzsch, J.; Sergeyev, E.; Lipek, T.; Vogel, M.; Spielau, U.; Korner, A.; et al. Novel insights in the metabolic syndrome in childhood and adolescence. Horm. Res. Paediatr. 2017, 88, 181-193. [CrossRef]

25. Pugazhenthi, S. Metabolic syndrome and the cellular phase of Alzheimer's disease. Prog. Mol. Biol. Transl. Sci. 2017, 146, 243-258. [CrossRef]

26. Blais, A.; Drouin, G.; Chaumontet, C.; Voisin, T.; Couvelard, A.; Even, P.C.; Couvineau, A. Impact of Orexin-A treatment on food intake, energy metabolism and body weight in mice. PLoS ONE 2017, 12, e0169908. [CrossRef]

27. Yi, M.; Li, H.; Wu, Z.; Yan, J.; Liu, Q.; Ou, C.; Chen, M. A promising therapeutic target for metabolic diseases: Neuropeptide Y receptors in humans. Cell Physiol. Biochem. 2018, 45, 88-107. [CrossRef]

28. Lawson, E.A. The effects of oxytocin on eating behaviour and metabolism in humans. Nat. Rev. Endocrinol. 2017, 13, 700-709. [CrossRef]

29. Frolich, L.; Blum-Degen, D.; Bernstein, H.G.; Engelsberger, S.; Humrich, J.; Laufer, S.; Muschner, D.; Thalheimer, A.; Turk, A.; Hoyer, S.; et al. Brain insulin and insulin receptors in aging and sporadic Alzheimer's disease. J. Neural. Transm. 1998, 105, 423-438. [CrossRef]

30. Kim, M.W.; Abid, N.B.; Jo, M.H.; Jo, M.G.; Yoon, G.H.; Kim, M.O. Suppression of adiponectin receptor 1 promotes memory dysfunction and Alzheimer's disease-like pathologies. Sci. Rep. 2017, 7, 12435. [CrossRef]

31. Song, J.; Lee, J.E. Adiponectin as a new paradigm for approaching Alzheimer's disease. Anat. Cell Biol. 2013, 46, 229-234. [CrossRef] 
32. Nasoohi, S.; Parveen, K.; Ishrat, T. Metabolic syndrome, brain insulin resistance, and Alzheimer's disease: Thioredoxin interacting protein (TXNIP) and inflammasome as core amplifiers. J. Alzheimers Dis. 2018, 66, 857-885. [CrossRef] [PubMed]

33. Willette, A.A.; Xu, G.; Johnson, S.C.; Birdsill, A.C.; Jonaitis, E.M.; Sager, M.A.; Hermann, B.P.; la Rue, A.; Asthana, S.; Bendlin, B.B.; et al. Insulin resistance, brain atrophy, and cognitive performance in late middle-aged adults. Diabetes Care 2013, 36, 443-449. [CrossRef] [PubMed]

34. De la Monte, S.M. Insulin resistance and neurodegeneration: Progress towards the development of new therapeutics for Alzheimer's disease. Drugs 2017, 77, 47-65. [CrossRef] [PubMed]

35. Cao, H. Adipocytokines in obesity and metabolic disease. J. Endocrinol. 2014, 220, T47-T59. [CrossRef]

36. Hotta, K.; Funahashi, T.; Bodkin, N.L.; Ortmeyer, H.K.; Arita, Y.; Hansen, B.C.; Matsuzawa, Y. Circulating concentrations of the adipocyte protein adiponectin are decreased in parallel with reduced insulin sensitivity during the progression to type 2 diabetes in rhesus monkeys. Diabetes 2001, 50, 1126-1133. [CrossRef]

37. Yamauchi, T.; Kamon, J.; Waki, H.; Terauchi, Y.; Kubota, N.; Hara, K.; Mori, Y.; Ide, T.; Murakami, K.; Tsuboyama-Kasaoka, N.; et al. The fat-derived hormone adiponectin reverses insulin resistance associated with both lipoatrophy and obesity. Nat. Med. 2001, 7, 941-946. [CrossRef]

38. Yamauchi, T.; Nio, Y.; Maki, T.; Kobayashi, M.; Takazawa, T.; Iwabu, M.; Okada-Iwabu, M.; Kawamoto, S.; Kubota, N.; Kubota, T.; et al. Targeted disruption of AdipoR1 and AdipoR2 causes abrogation of adiponectin binding and metabolic actions. Nat. Med. 2007, 13, 332-339. [CrossRef]

39. Scherer, P.E.; Williams, S.; Fogliano, M.; Baldini, G.; Lodish, H.F. A novel serum protein similar to C1q, produced exclusively in adipocytes. J. Biol. Chem. 1995, 270, 26746-26749. [CrossRef]

40. Arita, Y.; Kihara, S.; Ouchi, N.; Takahashi, M.; Maeda, K.; Miyagawa, J.; Hotta, K.; Shimomura, I.; Nakamura, T.; Miyaoka, K.; et al. Paradoxical decrease of an adipose-specific protein, adiponectin, in obesity. Biochem. Biophys. Res. Commun. 1999, 257, 79-83. [CrossRef]

41. Turer, A.T.; Scherer, P.E. Adiponectin: Mechanistic insights and clinical implications. Diabetologia 2012, 55, 2319-2326. [CrossRef] [PubMed]

42. Pataky, Z.; Bobbioni-Harsch, E.; Golay, A. Obesity: A complex growing challenge. Exp. Clin. Endocrinol. Diabetes 2010, 118, 427-433. [CrossRef] [PubMed]

43. Emmerzaal, T.L.; Kiliaan, A.J.; Gustafson, D.R. 2003-2013: A decade of body mass index, Alzheimer's disease, and dementia. J. Alzheimers Dis. 2015, 43, 739-755. [CrossRef] [PubMed]

44. Lee, S.; Kim, J.Y.; Kim, E.; Seo, K.; Kang, Y.J.; Kim, J.Y.; Kim, C.H.; Song, H.T.; Saksida, L.M.; Lee, J.E.; et al. Assessment of cognitive impairment in a mouse model of high-fat diet-induced metabolic stress with touchscreen-based automated battery system. Exp. Neurobiol. 2018, 27, 277-286. [CrossRef]

45. Okada-Iwabu, M.; Yamauchi, T.; Iwabu, M.; Honma, T.; Hamagami, K.; Matsuda, K.; Yamaguchi, M.; Tanabe, H.; Kimura-Someya, T.; Shirouzu, M.; et al. A small-molecule AdipoR agonist for type 2 diabetes and short life in obesity. Nature 2013, 503, 493-499. [CrossRef]

46. Sekiyama, K.; Waragai, M.; Akatsu, H.; Sugama, S.; Takenouchi, T.; Takamatsu, Y.; Fujita, M.; Sekigawa, A.; Rockenstein, E.; Inoue, S.; et al. Disease-modifying effect of adiponectin in model of alpha-synucleinopathies. Ann. Clin. Transl. Neurol. 2014, 1, 479-489. [CrossRef]

47. Mao, X.; Kikani, C.K.; Riojas, R.A.; Langlais, P.; Wang, L.; Ramos, F.J.; Fang, Q.; Christ-Roberts, C.Y.; Hong, J.Y.; Kim, R.Y.; et al. APPL1 binds to adiponectin receptors and mediates adiponectin signalling and function. Nat. Cell Biol. 2006, 8, 516-523. [CrossRef]

48. XiaoTian, L.; QiNan, W.; XiaGuang, G.; WuQuan, D.; Bing, C.; ZiWen, L. Exenatide Activates the APPL1-AMPK-PPARalpha axis to prevent diabetic cardiomyocyte apoptosis. J. Diabetes Res. 2016, 2016, 4219735. [CrossRef]

49. Cheng, K.K.; Lam, K.S.; Wang, Y.; Huang, Y.; Carling, D.; Wu, D.; Wong, C.; Xu, A. Adiponectin-induced endothelial nitric oxide synthase activation and nitric oxide production are mediated by APPL1 in endothelial cells. Diabetes 2007, 56, 1387-1394. [CrossRef]

50. Chandrasekar, B.; Boylston, W.H.; Venkatachalam, K.; Webster, N.J.; Prabhu, S.D.; Valente, A.J. Adiponectin blocks interleukin-18-mediated endothelial cell death via APPL1-dependent AMP-activated protein kinase (AMPK) activation and IKK/NF-kappaB/PTEN suppression. J. Biol. Chem. 2008, 283, 24889-24898. [CrossRef]

51. Coope, A.; Milanski, M.; Araujo, E.P.; Tambascia, M.; Saad, M.J.; Geloneze, B.; Velloso, L.A. AdipoR1 mediates the anorexigenic and insulin/leptin-like actions of adiponectin in the hypothalamus. FEBS Lett. 2008, 582, 1471-1476. [CrossRef] [PubMed] 
52. Lee, M.H.; Klein, R.L.; El-Shewy, H.M.; Luttrell, D.K.; Luttrell, L.M. The adiponectin receptors AdipoR1 and AdipoR2 activate ERK1/2 through a Src/Ras-dependent pathway and stimulate cell growth. Biochemistry 2008, 47, 11682-11692. [CrossRef] [PubMed]

53. Thundyil, J.; Tang, S.C.; Okun, E.; Shah, K.; Karamyan, V.T.; Li, Y.I.; Woodruff, T.M.; Taylor, S.M.; Jo, D.G.; Mattson, M.P.; et al. Evidence that adiponectin receptor 1 activation exacerbates ischemic neuronal death. Exp. Transl. Stroke. Med. 2010, 2, 15. [CrossRef]

54. Parker-Duffen, J.L.; Nakamura, K.; Silver, M. T-cadherin is essential for adiponectin-mediated revascularization. J. Biol. Chem. 2013, 288, 24886-24897. [CrossRef] [PubMed]

55. Wang, M.; Jo, J.; Song, J. Adiponectin improves long-term potentiation in the 5XFAD mouse brain. Sci. Rep. 2019, 9, 8918. [CrossRef]

56. Zhang, D.; Wang, X.; Lu, X.Y. Adiponectin exerts neurotrophic effects on dendritic arborization, spinogenesis, and neurogenesis of the dentate gyrus of male mice. Endocrinology 2016, 157, 2853-2869. [CrossRef]

57. Yoon, G.; Shah, S.A.; Ali, T.; Kim, M.O. The adiponectin homolog osmotin enhances neurite outgrowth and synaptic complexity via AdipoR1/NgR1 Signaling in Alzheimer's Disease. Mol. Neurobiol. 2018, 55, 6673-6686. [CrossRef]

58. Ali, T.; Yoon, G.H.; Shah, S.A.; Lee, H.Y.; Kim, M.O. Osmotin attenuates amyloid beta-induced memory impairment, tau phosphorylation and neurodegeneration in the mouse hippocampus. Sci. Rep. 2015, 5, 11708. [CrossRef]

59. Shah, S.A.; Yoon, G.H.; Chung, S.S.; Abid, M.N.; Kim, T.H.; Lee, H.Y.; Kim, M.O. Novel osmotin inhibits SREBP2 via the AdipoR1/AMPK/SIRT1 pathway to improve Alzheimer's disease neuropathological deficits. Mol. Psychiatry 2017, 22, 407-416. [CrossRef]

60. Ng, R.C.; Cheng, O.Y.; Jian, M.; Kwan, J.S.; Ho, P.W.; Cheng, K.K.; Yeung, P.K.; Zhou, L.L.; Hoo, R.L.; Chung, S.K.; et al. Chronic adiponectin deficiency leads to Alzheimer's disease-like cognitive impairments and pathologies through AMPK inactivation and cerebral insulin resistance in aged mice. Mol. Neurodegener. 2016, 11, 71. [CrossRef]

61. Cezaretto, A.; Suemoto, C.K.; Bensenor, I.; Lotufo, P.A.; de Almeida-Pititto, B.; Ferreira, S.R.G.; Group, E.R. Association of adiponectin with cognitive function precedes overt diabetes in the Brazilian Longitudinal Study of Adult Health: ELSA. Diabetol. Metab. Syndr. 2018, 10, 54. [CrossRef] [PubMed]

62. Yamauchi, T.; Iwabu, M.; Okada-Iwabu, M.; Kadowaki, T. Adiponectin receptors: A review of their structure, function and how they work. Best Pract. Res. Clin. Endocrinol. Metab. 2014, 28, 15-23. [CrossRef] [PubMed]

63. Thundyil, J.; Pavlovski, D.; Sobey, C.G.; Arumugam, T.V. Adiponectin receptor signalling in the brain. Br. J. Pharmacol. 2012, 165, 313-327. [CrossRef]

64. Ebinuma, H.; Miida, T.; Yamauchi, T.; Hada, Y.; Hara, K.; Kubota, N.; Kadowaki, T. Improved ELISA for selective measurement of adiponectin multimers and identification of adiponectin in human cerebrospinal fluid. Clin. Chem. 2007, 53, 1541-1544. [CrossRef]

65. Yamauchi, T.; Kamon, J.; Ito, Y.; Tsuchida, A.; Yokomizo, T.; Kita, S.; Sugiyama, T.; Miyagishi, M.; Hara, K.; Tsunoda, M.; et al. Cloning of adiponectin receptors that mediate antidiabetic metabolic effects. Nature 2003, 423, 762-769. [CrossRef]

66. Deane, R.; Bell, R.D.; Sagare, A.; Zlokvic, B.V. Clearance of amyloid- $\beta$ peptide across the blood-brain barrier: Implication for therapies in Alzheimer's disease. CNS Neurol. Disord. Drug Targets 2009, 8, 16-30. [CrossRef]

67. Varhelyi, Z.P.; Kalman, J.; Olah, Z.; Ivitz, E.V.; Fodor, E.K.; Santha, M.; Datki, Z.L.; Pakaski, M. Adiponectin receptors are less sensitive to stress in a transgenic mouse model of Alzheimer's Disease. Front. Neurosci. 2017, 11, 199. [CrossRef] [PubMed]

68. Steen, E.; Terry, B.M.; Rivera, E.J.; Cannon, J.L.; Neely, T.R.; Tavares, R.; Xu, X.J.; Wands, J.R.; de la Monte, S.M. Impaired insulin and insulin-like growth factor expression and signaling mechanisms in Alzheimer's disease-Is this type 3 diabetes? J. Alzheimers Dis. 2005, 7, 63-80. [CrossRef]

69. Arnold, S.E.; Arvanitakis, Z.; Macauley-Rambach, S.L.; Koenig, A.M.; Wang, H.Y.; Ahima, R.S.; Craft, S.; Gandy, S.; Buettner, C.; Stoeckel, L.E.; et al. Brain insulin resistance in type 2 diabetes and Alzheimer disease: Concepts and conundrums. Nat. Rev. Neurol. 2018, 14, 168-181. [CrossRef] [PubMed]

70. De Felice, F.G. Alzheimer's disease and insulin resistance: Translating basic science into clinical applications. J. Clin. Investig. 2013, 123, 531-539. [CrossRef] 
71. Jack, C.R., Jr.; Petersen, R.C.; Xu, Y.; O’Brien, P.C.; Smith, G.E.; Ivnik, R.J.; Tangalos, E.G.; Kokmen, E. Rate of medial temporal lobe atrophy in typical aging and Alzheimer's disease. Neurology 1998, 51, 993-999. [CrossRef] [PubMed]

72. De Felice, F.G.; Vieira, M.N.; Bomfim, T.R.; Decker, H.; Velasco, P.T.; Lambert, M.P.; Viola, K.L.; Zhao, W.Q.; Ferreira, S.T.; Klein, W.L. Protection of synapses against Alzheimer's-linked toxins: Insulin signaling prevents the pathogenic binding of Abeta oligomers. Proc. Natl. Acad. Sci. USA 2009, 106, 1971-1976. [CrossRef] [PubMed]

73. Lopez-Jaramillo, P.; Gomez-Arbelaez, D.; Lopez-Lopez, J.; Lopez-Lopez, C.; Martinez-Ortega, J.; Gomez-Rodriguez, A.; Triana-Cubillos, S. The role of leptin/adiponectin ratio in metabolic syndrome and diabetes. Horm. Mol. Biol. Clin. Investig. 2014, 18, 37-45. [CrossRef] [PubMed]

74. Berg, A.H.; Combs, T.P.; Du, X.; Brownlee, M.; Scherer, P.E. The adipocyte-secreted protein Acrp30 enhances hepatic insulin action. Nat. Med. 2001, 7, 947-953. [CrossRef]

75. Masaki, T.; Anan, F.; Shimomura, T.; Fujiki, M.; Saikawa, T.; Yoshimatsu, H. Association between hippocampal volume and serum adiponectin in patients with type 2 diabetes mellitus. Metabolism 2012, 61, 1197-1200. [CrossRef]

76. Garcia-Casares, N.; Garcia-Arnes, J.A.; Rioja, J.; Ariza, M.J.; Gutierrez, A.; Alfaro, F.; Nabrozidis, A.; Gonzalez-Alegre, P.; Gonzalez-Santos, P. Alzheimer's like brain changes correlate with low adiponectin plasma levels in type 2 diabetic patients. J. Diabetes Complicat. 2016, 30, 281-286. [CrossRef]

77. Xu, Z.P.; Gan, G.S.; Liu, Y.M.; Xiao, J.S.; Liu, H.X.; Mei, B.; Zhang, J.J. adiponectin attenuates streptozotocin-induced tau hyperphosphorylation and cognitive deficits by rescuing PI3K/Akt/GSK-3beta pathway. Neurochem. Res. 2018, 43, 316-323. [CrossRef]

78. Butterfield, D.A.; Halliwell, B. Oxidative stress, dysfunctional glucose metabolism and Alzheimer disease. Nat. Rev. Neurosci. 2019, 20, 148-160. [CrossRef]

79. Cunnane, S.; Nugent, S.; Roy, M.; Courchesne-Loyer, A.; Croteau, E.; Tremblay, S.; Castellano, A.; Pifferi, F.; Bocti, C.; Paquet, N.; et al. Brain fuel metabolism, aging, and Alzheimer's disease. Nutrition 2011, 27, 3-20. [CrossRef]

80. Jack, C.R., Jr.; Knopman, D.S.; Jagust, W.J.; Shaw, L.M.; Aisen, P.S.; Weiner, M.W.; Petersen, R.C.; Trojanowski, J.Q. Hypothetical model of dynamic biomarkers of the Alzheimer's pathological cascade. Lancet Neurol. 2010, 9, 119-128. [CrossRef]

81. Small, G.W.; Mazziotta, J.C.; Collins, M.T.; Baxter, L.R.; Phelps, M.E.; Mandelkern, M.A.; Kaplan, A.; La Rue, A.; Adamson, C.F.; Chang, L.; et al. Apolipoprotein E type 4 allele and cerebral glucose metabolism in relatives at risk for familial Alzheimer disease. JAMA 1995, 273, 942-947. [CrossRef]

82. Cisternas, P.; Martinez, M.; Ahima, R.S.; William Wong, G.; Inestrosa, N.C. Modulation of Glucose Metabolism in Hippocampal Neurons by Adiponectin and Resistin. Mol. Neurobiol. 2019, 56, 3024-3037. [CrossRef]

83. Dienel, G.A.; Cruz, N.F. Nutrition during brain activation: Does cell-to-cell lactate shuttling contribute significantly to sweet and sour food for thought? Neurochem. Int. 2004, 45, 321-351. [CrossRef]

84. Dienel, G.A.; Hertz, L. Glucose and lactate metabolism during brain activation. J. Neurosci. Res. 2001, 66, 824-838. [CrossRef] [PubMed]

85. Dhopeshwarkar, G.A.; Mead, J.F. Fatty acid uptake by the brain. 3. Incorporation of (1-14C)oleic acid into the adult rat brain. Biochim. Biophys. Acta 1970, 210, 250-256. [CrossRef]

86. Panov, A.; Orynbayeva, Z.; Vavilin, V.; Lyakhovich, V. Fatty acids in energy metabolism of the central nervous system. Biomed. Res. Int. 2014, 2014, 472459. [CrossRef] [PubMed]

87. Schonfeld, P.; Reiser, G. Why does brain metabolism not favor burning of fatty acids to provide energy? Reflections on disadvantages of the use of free fatty acids as fuel for brain. J. Cereb. Blood Flow. Metab. 2013, 33, 1493-1499. [CrossRef]

88. Se Oliveira, C.; de Mattos, A.B.; Biz, C.; Oyama, L.M.; Ribeiro, E.B.; do Nascimento, C.M. High-fat diet and glucocorticoid treatment cause hyperglycemia associated with adiponectin receptor alterations. Lipids Health Dis. 2011, 10, 11. [CrossRef]

89. Yanai, H.; Yoshida, H. Beneficial effects of adiponectin on glucose and lipid metabolism and atherosclerotic progression: Mechanisms and perspectives. Int. J. Mol. Sci. 2019, 20, 1190. [CrossRef]

90. Yamauchi, T.; Kadowaki, T. Adiponectin receptor as a key player in healthy longevity and obesity-related diseases. Cell Metab. 2013, 17, 185-196. [CrossRef] 
91. Elfeky, M.; Kaede, R.; Okamatsu-Ogura, Y.; Kimura, K. Adiponectin inhibits LPS-induced HMGB1 release through an AMP kinase and heme oxygenase-1-dependent pathway in RAW 264 macrophage cells. Mediators Inflamm. 2016, 2016, 5701959. [CrossRef] [PubMed]

92. Rizzo, F.R.; Musella, A.; de Vito, F.; Fresegna, D.; Bullitta, S.; Vanni, V.; Guadalupi, L.; Stampanoni Bassi, M.; Buttari, F.; Mandolesi, G.; et al. Tumor necrosis factor and interleukin-1beta modulate synaptic plasticity during neuroinflammation. Neural. Plast. 2018, 2018, 8430123. [CrossRef] [PubMed]

93. Ferreira, S.T.; Clarke, J.R.; Bomfim, T.R.; De Felice, F.G. Inflammation, defective insulin signaling, and neuronal dysfunction in Alzheimer's disease. Alzheimers Dement. 2014, 10, S76-S83. [CrossRef] [PubMed]

94. Fruhbeck, G.; Catalan, V.; Rodriguez, A.; Ramirez, B.; Becerril, S.; Salvador, J.; Portincasa, P.; Colina, I.; Gomez-Ambrosi, J. Involvement of the leptin-adiponectin axis in inflammation and oxidative stress in the metabolic syndrome. Sci. Rep. 2017, 7, 6619. [CrossRef] [PubMed]

95. Yokota, T.; Oritani, K.; Takahashi, I.; Ishikawa, J.; Matsuyama, A.; Ouchi, N.; Kihara, S.; Funahashi, T.; Tenner, A.J.; Tomiyama, Y.; et al. Adiponectin, a new member of the family of soluble defense collagens, negatively regulates the growth of myelomonocytic progenitors and the functions of macrophages. Blood 2000, 96, 1723-1732. [CrossRef]

96. Lourenco, M.V.; Clarke, J.R.; Frozza, R.L.; Bomfim, T.R.; Forny-Germano, L.; Batista, A.F.; Sathler, L.B.; Brito-Moreira, J.; Amaral, O.B.; Silva, C.A.; et al. TNF-alpha mediates PKR-dependent memory impairment and brain IRS-1 inhibition induced by Alzheimer's beta-amyloid oligomers in mice and monkeys. Cell Metab. 2013, 18, 831-843. [CrossRef] [PubMed]

97. Nicolas, S.; Cazareth, J.; Zarif, H.; Guyon, A.; Heurteaux, C.; Chabry, J.; Petit-Paitel, A. Globular adiponectin limits microglia pro-inflammatory phenotype through an AdipoR1/NF-kappaB signaling pathway. Front. Cell Neurosci. 2017, 11, 352. [CrossRef]

98. Chabry, J.; Nicolas, S.; Cazareth, J.; Murris, E.; Guyon, A.; Glaichenhaus, N.; Heurteaux, C.; Petit-Paitel, A. Enriched environment decreases microglia and brain macrophages inflammatory phenotypes through adiponectin-dependent mechanisms: Relevance to depressive-like behavior. Brain Behav. Immun. 2015, 50, 275-287. [CrossRef]

99. Tonnies, E.; Trushina, E. Oxidative stress, synaptic dysfunction, and Alzheimer's disease. J. Alzheimers Dis. 2017, 57, 1105-1121. [CrossRef]

100. Snyder, B.; Shell, B.; Cunningham, J.T.; Cunningham, R.L. Chronic intermittent hypoxia induces oxidative stress and inflammation in brain regions associated with early-stage neurodegeneration. Physiol. Rep. 2017, 5. [CrossRef] [PubMed]

101. Chan, K.H.; Lam, K.S.; Cheng, O.Y.; Kwan, J.S.; Ho, P.W.; Cheng, K.K.; Chung, S.K.; Ho, J.W.; Guo, V.Y.; $\mathrm{Xu}, \mathrm{A}$. Adiponectin is protective against oxidative stress induced cytotoxicity in amyloid- $\beta$ neurotoxicity. PLoS ONE 2012, 7, e52354. [CrossRef] [PubMed]

102. Park, M.; Youn, B.; Zheng, X.L.; Wu, D.; Xu, A.; Sweeney, G. Globular adiponectin, acting via AdipoR1/APPL1, protects $\mathrm{H} 9 \mathrm{c} 2$ cells from hypoxia/reoxygenation-induced apoptosis. PLoS ONE 2011, 6, e19143. [CrossRef] [PubMed]

103. Qiu, G.; Wan, R.; Hu, J.; Mattson, M.P.; Spangler, E.; Liu, S.; Yau, S.Y.; Lee, T.M.; Gleichmann, M.; Ingram, D.K.; et al. Adiponectin protects rat hippocampal neurons against excitotoxicity. Age 2011, 33, 155-165. [CrossRef] [PubMed]

104. Ramamurthy, S.; Ronnett, G.V. Developing a head for energy sensing: AMP-activated protein kinase as a multifunctional metabolic sensor in the brain. J. Physiol. 2006, 574, 85-93. [CrossRef]

105. Kubota, N.; Yano, W.; Kubota, T.; Yamauchi, T.; Itoh, S.; Kumagai, H.; Kozono, H.; Takamoto, I.; Okamoto, S.; Shiuchi, T.; et al. Adiponectin stimulates AMP-activated protein kinase in the hypothalamus and increases food intake. Cell Metab. 2007, 6, 55-68. [CrossRef]

106. Girgis, C.M.; Cheng, K.; Scott, C.H.; Gunton, J.E. Novel links between HIFs, type 2 diabetes, and metabolic syndrome. Trends Endocrinol. Metab. 2012, 23, 372-380. [CrossRef]

107. Jiang, C.; Kim, J.H.; Li, F.; Qu, A.; Gavrilova, O.; Shah, Y.M.; Gonzalez, F.J. Hypoxia-inducible factor $1 \alpha$ regulates a SOCS3-STAT3-adiponectin signal transduction pathway in adipocytes. J. Biol. Chem. 2013, 288, 3844-3857. [CrossRef]

108. Bai, H.; Zhao, L.; Liu, H.; Guo, H.; Guo, W.; Zheng, L.; Liu, X.; Wu, X.; Luo, J.; Li, X.; et al. Adiponectin confers neuroprotection against cerebral ischemia-reperfusion injury through activating the cAMP/PKA-CREB-BDNF signaling. Brain Res. Bull. 2018, 143, 145-154. [CrossRef] 
109. Wang, S.; Li, D.; Huang, C.; Wan, Y.; Wang, J.; Zan, X.; Yang, B. Overexpression of adiponectin alleviates intracerebral hemorrhage-induced brain injury in rats via suppression of oxidative stress. Neurosci. Lett. 2018, 681, 110-116. [CrossRef]

110. Choi, S.H.; Bylykbashi, E.; Chatila, Z.K.; Lee, S.W.; Pulli, B.; Clemenson, G.D.; Kim, E.; Rompala, A.; Oram, M.K.; Asselin, C.; et al. Combined adult neurogenesis and BDNF mimic exercise effects on cognition in an Alzheimer's mouse model. Science 2018, 361, eaan8821. [CrossRef]

111. Moreno-Jiménez, E.P.; Flor-García, M.; Terreros-Roncal, J.; Rábano, A.; Cafini, F.; Pallas-Bazarra, N.; Ávila, J.; Llorens-Martín, M. Adult hippocampal neurogenesis is abundant in neurologically healthy subjects and drops sharply in patients with Alzheimer's disease. Nat. Med. 2019, 25, 554-560. [CrossRef] [PubMed]

112. Song, J.; Kang, S.M.; Kim, E.; Kim, C.H.; Song, H.T.; Lee, J.E. Adiponectin receptor-mediated signaling ameliorates cerebral cell damage and regulates the neurogenesis of neural stem cells at high glucose concentrations: An in vivo and in vitro study. Cell Death Dis. 2015, 6, e1844. [CrossRef] [PubMed]

113. Teixeira, A.L.; Diniz, B.S.; Campos, A.C.; Miranda, A.S.; Rocha, N.P.; Talib, L.L.; Gattaz, W.F.; Forlenza, O.V. Decreased levels of circulating adiponectin in mild cognitive impairment and Alzheimer's disease. Neuromol. Med. 2013, 15, 115-121. [CrossRef] [PubMed]

114. Kamogawa, K.; Kohara, K.; Tabara, Y.; Uetani, E.; Nagai, T.; Yamamoto, M.; Igase, M.; Miki, T. Abdominal fat, adipose-derived hormones and mild cognitive impairment: The J-SHIPP study. Dement. Geriatr. Cogn. Disord. 2010, 30, 432-439. [CrossRef]

115. Gorska-Ciebiada, M.; Saryusz-Wolska, M.; Borkowska, A.; Ciebiada, M.; Loba, J. Adiponectin, leptin and IL-1 $\beta$ in elderly diabetic patients with mild cognitive impairment. Metab. Brain Dis. 2016, 31, 257-266. [CrossRef]

116. Kitagawa, K.; Miwa, K.; Okazaki, S.; Sakaguchi, M.; Mochizuki, H. Serum high-molecular-weight adiponectin level and incident dementia in patients with vascular risk factors. Euro. J. Neurol. 2016, 23, 641-647. [CrossRef]

117. Bigalke, B.; Schreitmüller, B.; Sopova, K.; Paul, A.; Stransky, E.; Gawaz, M.; Stellos, K.; Laske, C. Adipocytokines and CD34 progenitor cells in Alzheimer's disease. PLoS ONE 2011, 6, e20286. [CrossRef]

118. Hardie, D.G. AMP-activated protein kinase: An energy sensor that regulates all aspects of cell function. Genes Dev. 2011, 25, 1895-1908. [CrossRef]

119. Ruderman, N.B.; Xu, X.J.; Nelson, L.; Cacicedo, J.M.; Saha, A.K.; Lan, F.; Ido, Y. AMPK and SIRT1: A long-standing partnership? Am. J. Physiol Endocrinol. Metab. 2010, 298, E751-E760. [CrossRef]

120. Badshah, H.; Ali, T.; Kim, M.O. Osmotin attenuates LPS-induced neuroinflammation and memory impairments via the TLR4/NFkappaB signaling pathway. Sci. Rep. 2016, 6, 24493. [CrossRef]

121. Nicolas, S.; Debayle, D.; Bechade, C.; Maroteaux, L.; Gay, A.S.; Bayer, P.; Heurteaux, C.; Guyon, A.; Chabry, J. Adiporon, an adiponectin receptor agonist acts as an antidepressant and metabolic regulator in a mouse model of depression. Transl. Psychiatry 2018, 8, 159. [CrossRef] [PubMed]

122. Zhang, D.; Wang, X.; Wang, B.; Garza, J.C.; Fang, X.; Wang, J.; Scherer, P.E.; Brenner, R.; Zhang, W.; Lu, X.Y. Adiponectin regulates contextual fear extinction and intrinsic excitability of dentate gyrus granule neurons through AdipoR2 receptors. Mol. Psychiatry 2017, 22, 1044-1055. [CrossRef] [PubMed]

123. Liu, B.; Liu, J.; Wang, J.G.; Liu, C.L.; Yan, H.J. AdipoRon improves cognitive dysfunction of Alzheimer's disease and rescues impaired neural stem cell proliferation through AdipoR1/AMPK pathway. Exp. Neurol. 2020, 327, 113249. [CrossRef]

124. FDA approves memantine drug for treating AD. Am. J. Alzheimers Dis. Other Demen. 2003, 18, 329-330.

125. Pákáski, M.; Fehér, A.; Juhász, A.; Drótos, G.; Fazekas, O.C.; Kovács, J.; Janka, Z.; Kálmán, J. Serum adipokine levels modified by donepezil treatment in Alzheimer's disease. J. Alzheimers Dis. 2014, 38, 371-377. [CrossRef]

126. Ali, M.A.; El-Abhar, H.S.; Kamel, M.A.; Attia, A.S. Antidiabetic Effect of Galantamine: Novel Effect for a Known centrally acting drug. PLoS ONE 2015, 10, e0134648. [CrossRef]

127. Song, X.; Jensen, M.O.; Jogini, V.; Stein, R.A.; Lee, C.H.; McHaourab, H.S.; Shaw, D.E.; Gouaux, E. Mechanism of NMDA receptor channel block by MK-801 and memantine. Nature 2018, 556, 515-519. [CrossRef]

128. Liu, B.; Liu, J.; Wang, J.; Sun, F.; Jiang, S.; Hu, F.; Wang, D.; Liu, D.; Liu, C.; Yan, H. Adiponectin protects against cerebral ischemic injury through AdipoR1/AMPK pathways. Front. Pharmacol. 2019, 10, 597. [CrossRef]

129. Yue, L.; Zhao, L.; Liu, H.; Li, X.; Wang, B.; Guo, H.; Gao, L.; Feng, D.; Qu, Y. Adiponectin Protects against Glutamate-Induced Excitotoxicity via Activating SIRT1-Dependent PGC-1alpha Expression in HT22 Hippocampal Neurons. Oxid. Med. Cell Longev. 2016, 2016, 2957354. [CrossRef] 
130. Shah, S.A.; Lee, H.Y.; Bressan, R.A.; Yun, D.J.; Kim, M.O. Novel osmotin attenuates glutamate-induced synaptic dysfunction and neurodegeneration via the JNK/PI3K/Akt pathway in postnatal rat brain. Cell Death Dis. 2014, 5, e1026. [CrossRef]

131. Tumminia, A.; Vinciguerra, F.; Parisi, M.; Frittitta, L. Type 2 Diabetes mellitus and Alzheimer's disease: Role of insulin signalling and therapeutic implications. Int. J. Mol. Sci. 2018, 19, 3306. [CrossRef] [PubMed]

132. Li, J.; Xue, Y.M.; Zhu, B.; Pan, Y.H.; Zhang, Y.; Wang, C.; Li, Y. rosiglitazone elicits an adiponectin-mediated insulin-sensitizing action at the adipose tissue-liver axis in otsuka long-evans tokushima fatty rats. J. Diabetes Res. 2018, 2018, 4627842. [CrossRef] [PubMed]

133. American Diabetes, A. 9. Pharmacologic approaches to glycemic treatment: Standards of medical care in diabetes-2019. Diabetes Care 2019, 42, S90-S102. [CrossRef] [PubMed]

134. Kickstein, E.; Krauss, S.; Thornhill, P.; Rutschow, D.; Zeller, R.; Sharkey, J.; Williamson, R.; Fuchs, M.; Kohler, A.; Glossmann, H.; et al. Biguanide metformin acts on tau phosphorylation via mTOR/protein phosphatase 2A (PP2A) signaling. Proc. Natl. Acad. Sci. USA 2010, 107, 21830-21835. [CrossRef]

135. Gupta, A.; Bisht, B.; Dey, C.S. Peripheral insulin-sensitizer drug metformin ameliorates neuronal insulin resistance and Alzheimer's-like changes. Neuropharmacology 2011, 60, 910-920. [CrossRef]

136. Li, J.; Deng, J.; Sheng, W.; Zuo, Z. Metformin attenuates Alzheimer's disease-like neuropathology in obese, leptin-resistant mice. Pharmacol. Biochem. Behav. 2012, 101, 564-574. [CrossRef]

137. Luchsinger, J.A.; Perez, T.; Chang, H.; Mehta, P.; Steffener, J.; Pradabhan, G.; Ichise, M.; Manly, J.; Devanand, D.P.; Bagiella, E. Metformin in amnestic mild cognitive impairment: Results of a pilot randomized placebo controlled clinical trial. J. Alzheimer Disease JAD 2016, 51, 501-514. [CrossRef]

138. Hsu, C.C.; Wahlqvist, M.L.; Lee, M.S.; Tsai, H.N. Incidence of dementia is increased in type 2 diabetes and reduced by the use of sulfonylureas and metformin. J. Alzheimer Disease JAD 2011, 24, 485-493. [CrossRef]

139. Abbas, N.A.T.; El Salem, A. Metformin, sitagliptin, and liraglutide modulate serum retinol-binding protein-4 level and adipocytokine production in type 2 diabetes mellitus rat model. Can. J. Physiol. Pharmacol. 2018, 96, 1226-1231. [CrossRef]

140. Su, J.R.; Lu, Z.H.; Su, Y.; Zhao, N.; Dong, C.L.; Sun, L.; Zhao, S.F.; Li, Y. relationship of serum adiponectin levels and metformin therapy in patients with type 2 diabetes. Horm. Metab. Res. 2016, 48, 92-98. [CrossRef]

141. Chiang, M.C.; Cheng, Y.C.; Chen, S.J.; Yen, C.H.; Huang, R.N. Metformin activation of AMPK-dependent pathways is neuroprotective in human neural stem cells against Amyloid-beta-induced mitochondrial dysfunction. Exp. Cell Res. 2016, 347, 322-331. [CrossRef] [PubMed]

142. Kong, W.; Niu, X.; Zeng, T.; Lu, M.; Chen, L. Impact of treatment with metformin on adipocytokines in patients with polycystic ovary syndrome: A meta-analysis. PLoS ONE 2015, 10, e0140565. [CrossRef]

143. Chung, M.M.; Chen, Y.L.; Pei, D.; Cheng, Y.C.; Sun, B.; Nicol, C.J.; Yen, C.H.; Chen, H.M.; Liang, Y.J.; Chiang, M.C. The neuroprotective role of metformin in advanced glycation end product treated human neural stem cells is AMPK-dependent. Biochim. Biophys. Acta 2015, 1852, 720-731. [CrossRef] [PubMed]

144. Saltiel, A.R.; Olefsky, J.M. Thiazolidinediones in the treatment of insulin resistance and type II diabetes. Diabetes 1996, 45, 1661-1669. [CrossRef]

145. Malinowski, J.M.; Bolesta, S. Rosiglitazone in the treatment of type 2 diabetes mellitus: A critical review. Clin. Ther. 2000, 22, 1151-1168. [CrossRef]

146. Jojo, G.M.; Kuppusamy, G. Scope of new formulation approaches in the repurposing of pioglitazone for the management of Alzheimer's disease. J. Clin. Pharm. Ther. 2019, 44, 337-348. [CrossRef] [PubMed]

147. Silva-Abreu, M.; Gonzalez-Pizarro, R.; Espinoza, L.C.; Rodriguez-Lagunas, M.J.; Espina, M.; Garcia, M.L.; Calpena, A.C. Thiazolidinedione as an alternative to facilitate oral administration in geriatric patients with Alzheimer's disease. Eur. J. Pharm. Sci. 2019, 129, 173-180. [CrossRef]

148. Tsuchida, A.; Yamauchi, T.; Takekawa, S.; Hada, Y.; Ito, Y.; Maki, T.; Kadowaki, T. Peroxisome proliferator-activated receptor (PPAR)alpha activation increases adiponectin receptors and reduces obesity-related inflammation in adipose tissue: Comparison of activation of PPAR $\alpha$, PPAR $\gamma$, and their combination. Diabetes 2005, 54, 3358-3370. [CrossRef]

149. Holscher, C. Potential role of glucagon-like peptide-1 (GLP-1) in neuroprotection. CNS Drugs 2012, 26, 871-882. [CrossRef]

150. Kakimura, J.; Kitamura, Y.; Takata, K.; Umeki, M.; Suzuki, S.; Shibagaki, K.; Taniguchi, T.; Nomura, Y.; Gebicke-Haerter, P.J.; Smith, M.A.; et al. Microglial activation and amyloid-beta clearance induced by exogenous heat-shock proteins. FASEB J. 2002, 16, 601-603. [CrossRef] 
151. Perry, T.; Holloway, H.W.; Weerasuriya, A.; Mouton, P.R.; Duffy, K.; Mattison, J.A.; Greig, N.H. Evidence of GLP-1-mediated neuroprotection in an animal model of pyridoxine-induced peripheral sensory neuropathy. Exp. Neurol. 2007, 203, 293-301. [CrossRef]

152. Baggio, L.L.; Drucker, D.J. Glucagon-like peptide-1 receptors in the brain: Controlling food intake and body weight. J. Clin. Investig. 2014, 124, 4223-4226. [CrossRef]

153. During, M.J.; Cao, L.; Zuzga, D.S.; Francis, J.S.; Fitzsimons, H.L.; Jiao, X.; Bland, R.J.; Klugmann, M.; Banks, W.A.; Drucker, D.J.; et al. Glucagon-like peptide-1 receptor is involved in learning and neuroprotection. Nat. Med. 2003, 9, 1173-1179. [CrossRef]

154. Hamilton, A.; Holscher, C. Receptors for the incretin glucagon-like peptide-1 are expressed on neurons in the central nervous system. Neuroreport 2009, 20, 1161-1166. [CrossRef]

155. Wang, A.; Li, T.; An, P.; Yan, W.; Zheng, H.; Wang, B.; Mu, Y. Exendin-4 upregulates adiponectin level in adipocytes via Sirt1/Foxo-1 signaling pathway. PLoS ONE 2017, 12, e0169469. [CrossRef] [PubMed]

156. Ryan, D.; Acosta, A. GLP-1 receptor agonists: Nonglycemic clinical effects in weight loss and beyond. Obesity 2015, 23, 1119-1129. [CrossRef]

157. Gault, V.A.; Holscher, C. GLP-1 agonists facilitate hippocampal LTP and reverse the impairment of LTP induced by beta-amyloid. Eur. J. Pharmacol. 2008, 587, 112-117. [CrossRef]

158. Han, W.N.; Holscher, C.; Yuan, L.; Yang, W.; Wang, X.H.; Wu, M.N.; Qi, J.S. Liraglutide protects against amyloid-beta protein-induced impairment of spatial learning and memory in rats. Neurobiol. Aging. 2013, 34, 576-588. [CrossRef]

159. Batista, A.F.; Forny-Germano, L.; Clarke, J.R.; Lyra, E.S.N.M.; Brito-Moreira, J.; Boehnke, S.E.; Winterborn, A.; Coe, B.C.; Lablans, A.; Vital, J.F.; et al. The diabetes drug liraglutide reverses cognitive impairment in mice and attenuates insulin receptor and synaptic pathology in a non-human primate model of Alzheimer's disease. J. Pathol. 2018, 245, 85-100. [CrossRef]

160. Wicinski, M.; Socha, M.; Malinowski, B.; Wodkiewicz, E.; Walczak, M.; Gorski, K.; Slupski, M.; Pawlak-Osinska, K. Liraglutide and its neuroprotective properties-focus on possible biochemical mechanisms in Alzheimer's disease and cerebral ischemic events. Int. J. Mol. Sci. 2019, 20, 1050. [CrossRef]

161. Zhang, Y.; Xie, J.Z.; Xu, X.Y.; Hu, J.; Xu, T.; Jin, S.; Yang, S.J.; Wang, J.Z. Liraglutide ameliorates hyperhomocysteinemia-induced alzheimer-like pathology and memory deficits in rats via multi-molecular targeting. Neurosci. Bull. 2019, 35, 724-734. [CrossRef] [PubMed]

162. Cahn, A.; Cernea, S.; Raz, I. An update on DPP-4 inhibitors in the management of type 2 diabetes. Expert Opin. Emerg. Drugs 2016, 21, 409-419. [CrossRef] [PubMed]

163. Chen, S.; Zhou, M.; Sun, J.; Guo, A.; Fernando, R.L.; Chen, Y.; Peng, P.; Zhao, G.; Deng, Y. DPP-4 inhibitor improves learning and memory deficits and AD-like neurodegeneration by modulating the GLP-1 signaling. Neuropharmacology 2019, 157, 107668. [CrossRef] [PubMed]

164. Sahebkar, A.; Ponzo, V.; Bo, S. Effect of dipeptidyl peptidase-4 inhibitors on plasma adiponectin: A systematic review and meta-analysis of randomized controlled trials. Curr. Med. Chem. 2016, 23, 1356-1369. [CrossRef]

165. Kosaraju, J.; Holsinger, R.M.D.; Guo, L.; Tam, K.Y. Linagliptin, a dipeptidyl peptidase-4 inhibitor, mitigates cognitive deficits and pathology in the 3xTg-AD mouse model of Alzheimer's disease. Mol. Neurobiol. 2017, 54, 6074-6084. [CrossRef]

166. Isik, A.T.; Soysal, P.; Yay, A.; Usarel, C. The effects of sitagliptin, a DPP-4 inhibitor, on cognitive functions in elderly diabetic patients with or without Alzheimer's disease. Diabetes Res. Clin. Pract. 2017, 123, 192-198. [CrossRef]

167. Angelopoulou, E.; Piperi, C. DPP-4 inhibitors: A promising therapeutic approach against Alzheimer's disease. Ann. Transl. Med. 2018, 6, 255. [CrossRef]

168. Claassen, J.A. New cardiovascular targets to prevent late onset Alzheimer disease. Eur. J. Pharmacol. 2015, 763, 131-134. [CrossRef]

169. Montecucco, F.; Mach, F. Update on therapeutic strategies to increase adiponectin function and secretion in metabolic syndrome. Diabetes Obes. Metab. 2009, 11, 445-454. [CrossRef]

170. Mogi, M.; Li, J.M.; Tsukuda, K.; Iwanami, J.; Min, L.J.; Sakata, A.; Fujita, T.; Iwai, M.; Horiuchi, M. Telmisartan prevented cognitive decline partly due to PPAR-gamma activation. Biochem. Biophys. Res. Commun. 2008, 375, 446-449. [CrossRef] 
171. Takeda, S.; Sato, N.; Takeuchi, D.; Kurinami, H.; Shinohara, M.; Niisato, K.; Kano, M.; Ogihara, T.; Rakugi, H.; Morishita, R. Angiotensin receptor blocker prevented beta-amyloid-induced cognitive impairment associated with recovery of neurovascular coupling. Hypertension 2009, 54, 1345-1352. [CrossRef]

172. Ongali, B.; Nicolakakis, N.; Tong, X.K.; Aboulkassim, T.; Papadopoulos, P.; Rosa-Neto, P.; Lecrux, C.; Imboden, H.; Hamel, E. Angiotensin II type 1 receptor blocker losartan prevents and rescues cerebrovascular, neuropathological and cognitive deficits in an Alzheimer's disease model. Neurobiol. Dis. 2014, 68, 126-136. [CrossRef]

173. Saavedra, J.M. Evidence to consider angiotensin II receptor blockers for the treatment of early Alzheimer's disease. Cell Mol. Neurobiol. 2016, 36, 259-279. [CrossRef] [PubMed]

174. Li, W.; Zhang, J.W.; Lu, F.; Ma, M.M.; Wang, J.Q.; Suo, A.Q.; Bai, Y.Y.; Liu, H.Q. Effects of telmisartan on the level of $A \beta 1-42$, interleukin-1 $\beta$, tumor necrosis factor $\alpha$ and cognition in hypertensive patients with Alzheimer's disease. Zhonghua Yi Xue Za Zhi 2012, 92, 2743-2746.

175. Hsu, C.Y.; Huang, C.C.; Chan, W.L.; Huang, P.H.; Chiang, C.H.; Chen, T.J.; Chung, C.M.; Lin, S.J.; Chen, J.W.; Leu, H.B. Angiotensin-receptor blockers and risk of Alzheimer's disease in hypertension population-A nationwide cohort study. Circ. J. 2013, 77, 405-410. [CrossRef]

176. Benicky, J.; Sánchez-Lemus, E.; Pavel, J.; Saavedra, J.M. Anti-inflammatory effects of angiotensin receptor blockers in the brain and the periphery. Cell Mol. Neurobiol. 2009, 29, 781-792. [CrossRef] [PubMed]

177. Panahpour, H.; Nekooeian, A.A.; Dehghani, G.A. Candesartan attenuates ischemic brain edema and protects the blood-brain barrier integrity from ischemia/reperfusion injury in rats. Iran. Biomed. J. 2014, 18, $232-238$. [CrossRef]

178. So, G.; Nakagawa, S.; Morofuji, Y.; Hiu, T.; Hayashi, K.; Tanaka, K.; Suyama, K.; Deli, M.A.; Nagata, I.; Matsuo, T.; et al. Candesartan improves ischemia-induced impairment of the blood-brain barrier in vitro. Cell Mol. Neurobiol. 2015, 35, 563-572. [CrossRef]

179. Clasen, R.; Schupp, M.; Foryst-Ludwig, A.; Sprang, C.; Clemenz, M.; Krikov, M.; Thone-Reineke, C.; Unger, T.; Kintscher, U. PPARgamma-activating angiotensin type-1 receptor blockers induce adiponectin. Hypertension 2005, 46, 137-143. [CrossRef]

180. Zorad, S.; Dou, J.T.; Benicky, J.; Hutanu, D.; Tybitanclova, K.; Zhou, J.; Saavedra, J.M. Long-term angiotensin II AT1 receptor inhibition produces adipose tissue hypotrophy accompanied by increased expression of adiponectin and PPARgamma. Eur. J. Pharmacol. 2006, 552, 112-122. [CrossRef] [PubMed]

181. Makita, S.; Abiko, A.; Naganuma, Y.; Moriai, Y.; Nakamura, M. Potential effects of angiotensin II receptor blockers on glucose tolerance and adiponectin levels in hypertensive patients. Cardiovasc. Drugs Ther. 2007, 21,317-318. [CrossRef] [PubMed]

182. Kohlstedt, K.; Gershome, C.; Trouvain, C.; Hofmann, W.K.; Fichtlscherer, S.; Fleming, I. Angiotensinconverting enzyme (ACE) inhibitors modulate cellular retinol-binding protein 1 and adiponectin expression in adipocytes via the ACE-dependent signaling cascade. Mol. Pharmacol. 2009, 75, 685-692. [CrossRef] [PubMed]

183. Fontana, V.; de Faria, A.P.C.; Oliveira-Paula, G.H.; Silva, P.S.; Biagi, C.; Tanus-Santos, J.E.; Moreno, H. Effects of angiotensin-converting enzyme inhibition on leptin and adiponectin levels in essential hypertension. Basic. Clin. Pharmacol. Toxicol. 2014, 114, 472-475. [CrossRef] [PubMed]

184. Hajjar, I.M.; Keown, M.; Lewis, P.; Almor, A. Angiotensin converting enzyme inhibitors and cognitive and functional decline in patients with Alzheimer's disease: An observational study. Am. J. Alzheimer Dis. Other Dement. 2008, 23, 77-83. [CrossRef]

185. Soto, M.E.; van Kan, G.A.; Nourhashemi, F.; Gillette-Guyonnet, S.; Cesari, M.; Cantet, C.; Rolland, Y.; Vellas, B. Angiotensin-converting enzyme inhibitors and Alzheimer's disease progression in older adults: Results from the Réseau sur la Maladie d'Alzheimer Français cohort. J. Am. Geriatr. Soc. 2013, 61, 1482-1488. [CrossRef]

186. De Oliveira, F.F.; Chen, E.S.; Smith, M.C.; Bertolucci, P.H.F. Pharmacogenetics of angiotensin-converting enzyme inhibitors in patients with Alzheimer's disease dementia. Curr. Alzheimer Res. 2018, 15, 386-398. [CrossRef]

187. Zhuang, S.; Wang, X.; Wang, H.F.; Li, J.; Wang, H.Y.; Zhang, H.Z.; Xing, C.M. Angiotensin converting enzyme serum activities: Relationship with Alzheimer's disease. Brain Res. 2016, 1650, 196-202. [CrossRef]

188. AbdAlla, S.; El Hakim, A.; Abdelbaset, A.; Elfaramawy, Y.; Quitterer, U. Inhibition of ACE Retards Tau hyperphosphorylation and signs of neuronal degeneration in aged rats subjected to chronic mild stress. Biomed. Res. Int. 2015, 2015, 917156. [CrossRef] 
189. AbdAlla, S.; Langer, A.; Fu, X.; Quitterer, U. ACE inhibition with captopril retards the development of signs of neurodegeneration in an animal model of Alzheimer's disease. Int. J. Mol. Sci. 2013, 14, 16917-16942. [CrossRef]

190. Dong, Y.F.; Kataoka, K.; Tokutomi, Y.; Nako, H.; Nakamura, T.; Toyama, K.; Sueta, D.; Koibuchi, N.; Yamamoto, E.; Ogawa, H.; et al. Perindopril, a centrally active angiotensin-converting enzyme inhibitor, prevents cognitive impairment in mouse models of Alzheimer's disease. FASEB J. 2011, 25, 2911-2920. [CrossRef]

191. Zhuang, S.; Wang, H.F.; Wang, X.; Li, J.; Xing, C.M. The association of renin-angiotensin system blockade use with the risks of cognitive impairment of aging and Alzheimer's disease: A meta-analysis. J. Clin. Neurosci. 2016, 33, 32-38. [CrossRef]

192. Bernstein, K.E.; Koronyo, Y.; Salumbides, B.C.; Sheyn, J.; Pelissier, L.; Lopes, D.H.J.; Shah, K.H.; Bernstein, E.A.; Fuchs, D.T.; Yu, J.J.Y.; et al. Angiotensin-converting enzyme overexpression in myelomonocytes prevents Alzheimer's-like cognitive decline. J. Clin. Investig. 2014, 124, 1000-1012. [CrossRef] [PubMed]

193. Liu, S.; Liu, J.; Miura, Y.; Tanabe, C.; Maeda, T.; Terayama, Y.; Turner, A.J.; Zou, K.; Komano, H. Conversion of $A \beta 43$ to $A \beta 40$ by the successive action of angiotensin-converting enzyme 2 and angiotensin-converting enzyme. J. Neurosci. Res. 2014, 92, 1178-1186. [CrossRef] [PubMed]

194. Zou, K.; Yamaguchi, H.; Akatsu, H.; Sakamoto, T.; Ko, M.; Mizoguchi, K.; Gong, J.-S.; Yu, W.; Yamamoto, T.; Kosaka, K.; et al. Angiotensin-converting enzyme converts amyloid beta-protein 1-42 (Abeta(1-42)) to Abeta(1-40), and its inhibition enhances brain Abeta deposition. J. Neurosci. 2007, 27, 8628-8635. [CrossRef] [PubMed]

195. Okopien, B.; Buldak, L.; Boldys, A. Fibrates in the management of atherogenic dyslipidemia. Expert Rev. Cardiovasc. Ther. 2017, 15, 913-921. [CrossRef] [PubMed]

196. Sahebkar, A.; Watts, G.F. Fibrate therapy and circulating adiponectin concentrations: A systematic review and meta-analysis of randomized placebo-controlled trials. Atherosclerosis 2013, 230, 110-120. [CrossRef]

197. D'Orio, B.; Fracassi, A.; Ceru, M.P.; Moreno, S. Targeting PPARalpha in Alzheimer's Disease. Curr. Alzheimer Res. 2018, 15, 345-354. [CrossRef]

198. Kai, T.; Arima, S.; Taniyama, Y.; Nakabou, M.; Kanamasa, K. Comparison of the effect of lipophilic and hydrophilic statins on serum adiponectin levels in patients with mild hypertension and dyslipidemia: Kinki Adiponectin Interventional (KAI) Study. Clin. Exp. Hypertens 2008, 30, 530-540. [CrossRef]

199. Qu, H.Y.; Xiao, Y.W.; Jiang, G.H.; Wang, Z.Y.; Zhang, Y.; Zhang, M. Effect of atorvastatin versus rosuvastatin on levels of serum lipids, inflammatory markers and adiponectin in patients with hypercholesterolemia. Pharm. Res. 2009, 26, 958-964. [CrossRef]

200. Tsutamoto, T.; Yamaji, M.; Kawahara, C.; Nishiyama, K.; Fujii, M.; Yamamoto, T.; Horie, M. Effect of simvastatin vs. rosuvastatin on adiponectin and haemoglobin A1c levels in patients with non-ischaemic chronic heart failure. Eur. J. Heart Fail. 2009, 11, 1195-1201. [CrossRef]

201. Guimaraes, E.S.; Cerda, A.; Dorea, E.L.; Bernik, M.M.S.; Gusukuma, M.C.; Pinto, G.A.; Fajardo, C.M.; Hirata, M.H.; Hirata, R.D.C. Effects of short-term add-on ezetimibe to statin treatment on expression of adipokines and inflammatory markers in diabetic and dyslipidemic patients. Cardiovasc. Ther. 2017, 35. [CrossRef] [PubMed]

202. Hu, Y.; Tong, G.; Xu, W.; Pan, J.; Ryan, K.; Yang, R.; Shuldiner, A.R.; Gong, D.W.; Zhu, D. Anti-inflammatory effects of simvastatin on adipokines in type 2 diabetic patients with carotid atherosclerosis. Diab. Vasc. Dis. Res. 2009, 6, 262-268. [CrossRef] [PubMed]

(C) 2020 by the authors. Licensee MDPI, Basel, Switzerland. This article is an open access article distributed under the terms and conditions of the Creative Commons Attribution (CC BY) license (http://creativecommons.org/licenses/by/4.0/). 